\title{
POLICE DISCRETION IN A CONTINENTAL EUROPEAN ADMINISTRATIVE STATE: THE POLICE OF BADEN-WÜRTTEMBERG IN THE FEDERAL REPUBLIC OF GERMANY
}

\author{
David K. LinNaN*

\section{INTRODUCTION}

In a West German state, the practical problems of governing and policing are similar to those found in the United States. Assuming legislative enactments of limited scope, how are these translated into operational policies as a general matter and applied in enforcement decisions at the individual level?! This article seeks to capture the institutional and operational essence of police discretion in West Germany by reference to three specific inquiries that look beyond the substantive law that empowers some action: (1) who makes a

Copyright @ 1984 by Law and Contemporary Problems
* Member of the California Bar. J.D., University of Chicago, 1979; B.A., Emory University,
1976. Legal research for this essay was done at the Max-Planck-Institut für ausländisches und inter-
nationales Strafrecht, Freiburg im Breisgau, West Germany, on a grant from the Alexander von
Humboldt Stiftung, whose support I gratefully acknowledge. I express special thanks to Professor
Dr. Hans-Heinrich Jescheck and Dr. Thomas Weigend of the Max Planck Institute, whose help was
invaluable through all phases of my work, as well as Prof. Dr. Albin Eser for continued access to the
Institute and its superior facilities. I also express my appreciation to the Baden-Württemberg Minis-
tries of the Interior and Justice, the Staatsanwaltschaft Freiburg and the Landespolizeischule Frei-
burg for their cooperation in the empirical aspects of my work. The opinions of the author
expressed herein are an outgrowth of an empirical study (in preparation) of police misconduct and
its control in West Germany conducted in $1980-1981$, and are based on interviews with and observa-
tions of police and prosecutors as well as examinations of police records and court files during that
period.

1. This Symposium relates most directly to an inquiry begun by Professor Kenneth Culp Davis in Discretionary Justice: A Preliminary Inquiry (1969), that sought to find a role for discretion in tailoring general categories of the law to individual justice. Professor Davis distinguished between reasonable and "extravagant" versions of the principle of the rule of law as a primary stumbling block in examinations of discretion. In a nutshell, the extravagant version maintains that all lawful government action is conducied in accordance with preexisting rules or guidelines. The reasonable version acknowledges that government agents outside the legislative branch not only enforce the law, but also make it. Is Professor Davis's argument with principles or with institutions? His analysis may be misplaced when applied to West German institutions, since a West German federal state is based on (and its police are subject to laws which take into account) what Professor Davis would term the extravagant version of the rule of law. Under the strict interpretation rejected by Professor Davis, theoretical discretion is largely a problem of enforcement and interpretation of existing laws. Indeed, Germans view legal discretion in these terms. See infra notes 4-22 and accompanying text. 
decision whether to take any action; (2) how is a choice made among the competing possibilities; and (3) whether an action once taken may be challenged and, if so, by whom.

Beyond scholarly interest, this examination of police discretion in Europe is important for what it reveals indirectly about the American scene. German law and political organization are different enough from that of the United States, ${ }^{2}$ however, to require an introduction before reaching the functional analysis of direct interest. This article commences with a survey of the general treatment of discretion in German public law. It then examines in greater detail the institutional and substantive law framework within which the modern police operate. Finally, the article explores empirical work concerning the West German police and their exercise of discretion. Before we evaluate any exercise of West German police discretion, we must understand West German police on their own terms. ${ }^{3}$

In comparison to Americans, the Germans try much harder to channel police actions through training and through accountability for actions after the fact. For jurisprudential and historical reasons, both popular and scholarly opinion are uncomfortable with the implications of unbridled governmental discretion. Nonetheless, current empirical work examining German

2. Examination of police discretion assumes an understanding of the organizational and substantive law framework within which the police operate. In Germany, one confronts an evolving institution in a modern continental European civil law administrative state that is supported by different political theories and with a historical background very different from English (and later, American) constitutional development. The police and their role in West German society have been in the public eye and changing since the late 1960's. The impetus for change has come from the social unrest resulting from successive broad political debates: student unrest in the late 1960's; Notstandsgesetzgebung (emergency powers for the government, enacted into the late 1960's); terrorist activities of the Baader-Meinhoff group, the Rote Armee Fraktion and various splinter groups in the early 1970's (currently enjoying a resurgence in attacks on NATO installations); a legal and political debate in the mid-1970's relating to the changes in the Federal Code of Criminal Procedure-the socalled lex Baader-Meinhoff-and police law (cast in the form of a government-sponsored new model police law and a counter-proposal from more liberal academics, the Musterentwurf eines einheitlichen Polizeigesetzes and the Alternativentwurf einheitlicher Polizeigesetze des Bundes und der Länder, respectively) involving both elements of neutral reform and expansion of police authority (in response to arguments that police did not have the tools to deal with civil disorder); civil disobedience in the late 1970 's related to radical political action and ecological concerns; recent social unrest related to the unavailability of housing in urban areas and police response to mass squatter actions; recent suggested reforms alleged to restrict political free speech by criminalizing certain misbehavior in demonstrations; and, currently, the fear that the otherwise legitimate peace movement may develop violent splinter groups opposing the stationing of new Pershing II and cruise missiles in Western Europe. Analogous to the American political scene in the late 1960's, the police have been criticized as "soft" by the political right and "repressive" by the political left. Incidental to episodic social unrest, the German police have enjoyed a long term upgrading of budgetary allocations for both personnel and equipment for domestic security (Innere Sicherheit), which has in curn altered the age structure and expectations of the police. Police management expects these changes to have long term effects.

3. This article aims to present a picture of the West German police in context and cannot lay claim to a comprehensive presentation of police law or criminal procedure constraints within which the West German police work. To pursue the substantive law in detail, the reader is directed to the selected German sources given in the footnotes. No systematic effort was made to include Englishlanguage treatments of subjects discussed herein, since many of the available materials are dated and concerns alluded to in this article can be pursued beyond the superficial level only in German materials. For the interested reader, however, the plea bargaining-prosecutorial discretion materials cited in note 62 are the best English-language materials and contain citations to older English materials. All translations herein are the author's. 
police discretion reaches the not very surprising conclusion that German police do make decisions and control outcomes beyond the bounds of their theoretically strictly limited freedom of action. From the standpoint of an American lawyer, however, this functional exercise of discretion pales in comparision to the apparent decision-channelling effect of prior training, professional incentives, managerial supervision on the job, and administrative and judicial review after the fact.

The guiding premise of this article is that discretion stands in a peculiar relationship to accountability in legal systems strictly adhering to the principle of the rule of law. In the administrative practice of a West German federal state, where bureaucratic acts are subject to internal and judicial review to a much greater extent than in the United States, shifting responsibility for decisions within the administrative hierarchy may constitute the functional equivalent of discretion. Viewed as a jurisdictional contest among various governmental organs, shifting responsibility for the entry level decision channels the subsequent review functions. This shifting comes to rest at the operational level of the police, where enforcement is subject to individual decisions.

What is the immediate relevance of the German experience for the American scene? On a primary level, the value of training (both in and outside the classroom) as affecting the exercise of discretion should be recognized. However, guidance through training requires the prior articulation of standards before they can be taught to officers. Apart from constitutional criminal procedure and despite the recognition that the policeman's job involves more than apprehending criminals, most American police are probably not provided with well-articulated standards to guide their more common decisions. In the absence of guidance, it is not surprising that similar cases produce different results. While differentiated solutions to challenges have validity in individual instances, increased diversity too often raises the spectre of legal uncertainty and arbitrariness, implicit criticisms of excessive police freedom of action.

Police management itself must organize training and remain primarily responsible for control of the individual officer's discretionary decisions. Nonetheless, the legal and political values embodied in training must come from the outside. Realistically, the extensive guidelines required for effective training (as well as the necessary investment of resources) place these matters beyond the capacity of smaller localities. Legislative direction is desirable, since the necessary detail entailed in the substantive law indicates the pedagogic unsuitability of after-the-fact case by case adjudication.

\section{II}

Executive Power and Its Exercise: Substantive Law Theory of Review in the Administrative State

The Federal Republic of Germany (and each of its constituent states, or Länder) is a continental European administrative state. What does this mean 
to the American lawyer trained in a decentralized government of limited powers? Beyond institutional organization, a very significant difference lies in the scope of the state's powers and responsibilities with respect to its citizens. As opposed to the United States' character as a liberal democracy with a government of limited powers, West Germany is a social democracy in which the government is actively charged with ensuring the well-being of its citizens. Americans are entitled only to nondiscrimination and to restraints on state power so that the state will not unduly encroach on liberty or property interests. West German citizens are entitled to the state's active provision for their well-being under the most modern view, but consequently are subject to the appropriation of their interests for the well-being of others. Yet institutional organization and state power are functionally related, since one is only the incorporation of the other as the instrument of governance.

The preceding statements should remind the American lawyer that in West Germany the relationship between the individual and the state (in the form of the state's highly visible police) is different. Reduced to a practical level, despite an unfortunate sociological tendency to lump the institutions of modern industrial democracies together, the German "cop on the beat" is not in the same position as his American counterpart.

The greater scope of state power, which has a historical basis, is harnessed in West Germany by administrative law. For the American reader, the term administrative law may be misleading; it implies a fairly narrow area of the law arising in connection with the specialized jurisprudence of agency actions and judicial review of those actions. By comparison, West German administrative law is more broadly conceived as that area of law governing not only intragovernmental organization and actions but also the details of the relationship between the individual and the state. ${ }^{4}$ On the practitioner's level, West German administrative law often approaches the American lawyer's sense of constitutional law.

West German administrative law provides a forum for case by case adjudication of what is "due" process. 5 This approach to government actions and discretion is implemented by the view that enforcement is merely a problem of interpreting existing law, such interpretations being subject to judicial review. ${ }^{6}$ Central to the administrative law review process is the concept of the "administrative act" (Verwaltungsakt), which may be generally defined as any externalized act of a public authority affecting an individual in the area of

4. See generally von Münch, Verwaltung und Verwaltungsrecht im demokratischen und sozialen Rechtsstaat, in Allgemeines Verwaltungsrecht 1-54 (H. Erichsen \& W. Martens 4th ed. 1979). See also infra notes $17-18$ and accompanying text.

5. On a functional level, West German administrative law has been characterized as closest in spirit to American constitutional law. Without detracting from the current German federal constitution, this level of codified law dates back to the late nineteenth century in relatively developed form and has survived modern German political and constitutional history-a roller coaster of monarchy, revolution, dictatorship, and republics-with more lasting effect at the individual level.

6. This point is the antithesis of Professor Davis's position, reflecting in large part a simple difference in his point of departure as an Anglo-American lawyer. See supra note 1 . 
public law. ${ }^{7}$ Limited chiefly by a concept related to mootness, ${ }^{8}$ administrative acts may be challenged within the administrative hierarchy of government and thereafter are subject to judicial review. ${ }^{9}$ West Germany employs courts of special administrative jurisdiction in which individuals may pursue review of administrative acts. These courts are busy. ${ }^{10}$

General administrative law standards of review incorporate doctrinal attitudes toward the complex problems of discretion in the enforcement mode of administration. As a point of departure, modern West German law does not recognize unbridled or free discretion (freies Ermessen). ${ }^{11}$ Technically, only well-tempered discretion (pflichtgemässe Ermessensausübung) is permissible, ${ }^{12}$ the limits of which are prescribed by the internal bounds of the statutes on which it is based. Yet, what is "well-tempered" discretion as a matter of law? 13

Using the exercise of state police power (health, safety, and welfare) as an example, we can observe the distinction made between the issue of whether

7. See generally Erichsen \& Martens, Das Verwallungshandeln, in Allgemeines VerwaltUNGSRECHT 137-220 (H. Erichsen \& W. Martens 4th ed. 1979).

8. A full technical analysis incorporates Rechtsschutzbedürnis and special case rules, which are neglected here.

9. See generally Badura, Das Verwaltungsverfahren, in Allgemeines Verwaltungsrecht 267-337 (H. Erichsen \& W. Martens 4th ed. 1979).

10. For example, in 1978 Baden-Würtemberg administrative courts disposed of 13,281 cases in the first instance and on appeal. Sratistisches Landesamt Baden-Württemberg, Das RechtsWESEN 1976 BIS 1978111 (1980) (state census office publication vol. 266).

11. E.g., H. Maurer, Allgemeines Verwaltungsrecht 89 (1980). In part a matter of semantics, modern views recognize the exercise of discretion but within the bounds of unbestimmle Rechtsbegriffe or Beurteilungsspielraum. Id. at 93-104. See also infra note 13.

12. E.g., Polizeigesetz of January 16, 1968 [PolG] § 3, Baden-Württemberg Gesetzblatt [GBI] 61 , as amended.

13. One commentator formulates as follows:

Simultaneously staying within while fully exhausting the possibilities of the bounds of discretion set forth in the law in question by balancing public against individual interests, while taking into account only those factors which might be inferred from the law's policy (and ignoring others), and adhering to principles of equal protection are the principal conditions for a correct exercise of discretion.

Translation of:

Die Einhaltung und andererseits die volle Ausschöpfung der vom jeweiligen Gesetz bestimmten Ermessensgrenzen durch Abwägung des öffentlichen mit dem Einzelinteresse, die Anwendung dem Zweck der Ermächtigung entsprechender, also nicht sachfremder Erwägung und die Beachtung des Gleichheitsgrundsatzes sind die Hauptvoraussetungen für eine fehlerfreie Ermessensentscheidung.

A. Wittern, Grundriss des VerWaltungsrechts 89 (1972).

While "well-tempered" discretion may be the best available translation, it fails to capture the nuance of a more literal translation of pfichtgemäss as "duty bound," which indicates external control. Control is imposed by and derived from the law, under the rule of law. However, "duty bound discretion," the more literal translation, is not preferable insofar as it contains the incongruity for English speakers of purporting to limit the manner of exercise rather than the scope of discretion. But is it "discretion" if the choices are limited and externally dictated? This linguistic tension relating to connotations of the word discretion is perhaps best relieved by the use of "well-tempered," as long as the reader remains conscious that the tempering agent is what Professor Davis called the extravagant version of the principle of the rule of law. See supra note 1 . There remains a sense among the minority of German administrative law scholars favoring Beurteilungsspielraum that there are areas of unreviewable discretion, see infra note 11 and sources cited therein, but this position seems to be losing ground, e.g., H. MAURER, supra note 11 , at 102-04, and is disfavored by the courts, id. at $96-97$. 
some action should be taken and the issue of which particular response among many is appropriate. The West German administrative lawyer focuses first on whether the elements of a disturbance of public order are present (an analysis of the so-called Tatbestandsseite). ${ }^{14}$ The corresponding reaction is viewed as an open choice, since more than one response is typically available under substantive law (an analysis of the so-called Rechtsfolgeseite). ${ }^{15}$ Reference to the police power, however, is only intellectual shorthand for the extent of lawful state regulation of, and intrusion into, the affairs of individuals. Many West German concepts that relate to public health, safety, and welfare or to public order are admittedly open-ended, but are treated in legal doctrine as indefinite legal norms (unbestimmte Rechtsbegriffe) subject to full review and adjudication. ${ }^{16}$ The German response side analysis involves a judgmental determination, but the parameters of discretion are the subject of substantive administrative law doctrines recapitulated in constitutional restraints. In practice, German courts recognize that there may be more than one right answer in a given situation, but do not shy away from examining executive actions on their merits while American courts often defer to separation of powers.

The substantive law principles are deceptively easy to state, but are no less involved in casuistic application than open-ended American constitutional principles. Foremost among them is the principle of proportionality (Verhältnismässigkeitsprinzip). ${ }^{17}$ This principle includes a choice of the least intrusive action (Übermassverbot) and suitability (Geeignetheit) ${ }^{18}$ aimed at furthering the purpose of the law in the application of which discretion is exercised. These concepts provide standards for limited review of discretionary decisions. The character and level of review far exceeds the "arbitrary and capricious" standard used by American courts reviewing agency actions. West German courts will not reverse administrative decisions with the benefit of hindsight, but they will test those decisions in light of available options at the time they were made. The possibility of review remains significant, since under modern West

14. See H. Wagner, Polizeirecht: kritisch dargestellt am Berliner ASOG, am Musterentwurf eines einheitlichen Polizeigesetzes und an der StPO 81-85 (1982) (practitioner's analysis). See also H. MAURER, supra note 11, at 86-93.

15. H. Maurer, supra note 11, at 86-93. A more theoretical if somewhat dated analysis is available in H. Schmatz, Die Grenzen des Opportunitätsprinzips im heutigen deutschen Polizeirecht (1966) (dissertation). Our analysis avoids the technical details of modern German inquiry such as Putativgefahr, Anscheingefahr, and Beurteilungsspielraum as being an interesting but unnecessary detour for purposes of this article. See also sources cited supra notes 11 \& 13.

16. E.g., H. MAURER, supra note 11, at 93-98. See also supra notes 11-14.

17. See, e.g., Bradley, The Exclusionary Rule in Germany, 96 HARv. L. REv. 1032, 1034-35, 1039-43 (1983), for a description in English. Since German doctrine treats the proportionality principle as an aspect of the Rechtsstaatsprinzip, K. Hesse, Grundzüge des VerfassungsRechts der BundesRepUbLik Deutschland 29, 77 (12th ed. 1980), it may legitimately be considered as related to the American "due process" concept.

18. In fact, these principles are elements of administrative law, see, e.g., 1 K. Vocel, Gefahrenabwehr: Allgemeines Polizeirecht (Ordnungsrecht) des Bundes und der Länder 135-73 (8th ed. 1975), so it is not necessary in typical cases to rise to the level of constitutional analysis. It may be more palatable to the American lawyer when cast in these terms, since it looks too much like substantive due process when viewed at the constitutional level. 
German law the individual has a right to the "correct exercise of discretion" (fehlerfreie Ermessungsausübung) in official action affecting him. At the extreme, discretion disappears when the disturbance of public order is serious and the response options are limited in number. ${ }^{19}$

Police are part of the administrative apparatus of governance and are generally subject to administrative law constraints. Thus, the availability of outside review extends to many if not all actions of the police. ${ }^{20}$ Police actions, whether discretionary or not, are theoretically subject to review by superiors, the civilian administration, and the judiciary. Due to memories of the Third Reich, the police are viewed critically by a significant segment of the populace and frequently attract media attention. ${ }^{21}$ The peculiar character of rights, not only as protection against the government, but also as entitlements to government action, also encourages many challenges for the failure to act. ${ }^{22}$

\section{III}

\section{The Institutional Framework of Law Enforcement in the Administrative State}

Is the German policeman just another one of the "boys in blue" who happens to speak a foreign language? No, but the depth of difference with the American experience first becomes apparent on examination of the institutional framework behind the individual officer. To place the preceding general treatment of discretion under German law in perspective, the police's role within the administrative apparatus of government must be addressed. To this end, a general description of the police is followed by a description of the substantive law and institutions which delimit the legal boundaries of their freedom of action in law enforcement.

19. See H. MaUrer, supra note 11 , at 92-93.

20. Until recently, courts declined to review many police actions, particularly those in the criminal procedure area, under a mootness analysis. This position has changed in the last decade. See generally Reiss \& Thyme, Rechtsschutz gegen strafprozessuale Zwangsmassnahmen, [1981] GoTTDAMMER's ARchIV 189 (criminal procedure); $2 \mathrm{~K}$. Vogel, supra note 18, at 361-423 (police law).

21. Talking with police management and examining local newspapers makes it apparent that police coverage and letters to the editor in the form of complaints play a significant role in smaller communities. While the larger city newspapers focus on more national and state news, the local newspaper or local edition of the regional rurai newspaper survives as an institution focusing on community affairs.

22. The closest American analogs may be the class action civil rights suit directed against a police department or, on rare occasions, federal investigations conducted by the Civil Rights Commission. Of course, the common wisdom among American litigators is that no police suit is complete without a civil rights count in the complaint and a criminal defendant's counsel is guilty of prima facie malpractice if he fails to make an exclusionary motion concerning evidence (if there is the barest colorable claim of police misconduct). However, the American parallels aim somewhat higher at egregious violations in individual instances, or at those involving patterns or practices if brought as class actions. 


\section{A. An Overview of the Structure of Police and Civil Administration in Baden-Württemberg}

West German police are organized on the state level ${ }^{23}$ as civil servants. ${ }^{24}$ The Criminal Code and Code of Criminal Procedure are federal laws, while administrative and police law matters are mostly retained under state jurisdiction. ${ }^{25}$ The legal principles and practical observations about police in this essay are largely based on the laws and police of the federal state of BadenWürttemberg, ${ }^{26}$ a jurisdiction located in the southwest corner of West Germany, approximately one and one-quarter times the size of Maryland, with a 1980 population of $9,190,052 .{ }^{27}$

It is instructive to note points of contrast between German police and their American counterparts as well as to compare the organization of civil governments under which they serve. ${ }^{28}$ As previously mentioned, the German police

23. See Appendix for schematic diagrams illustrating statewide organization and structure. The statewide organization has been challenged at times, in particular following World War II when the occupying powers tended to reorganize the police along the lines of their home countries as part of general denazification efforts. The American zone included the northern areas of present-day Baden-Württemberg, where they attempted to decentralize the police. See 25 JaHre LANDESPOLIZEIDIREKTION NORDbaden: ENTSTEhUNG UND ENTWiCKLUNG DER LANDESPOLIZEI iN NoRDBADEN NACH DEM 2. WeltKreig 23 (1970) (police report). The traditional system has replaced this foreign intrusion. See infra note 56. For a more general post-World War II picture of developments, see E. Raible, Geschichte der Polizei: ihre Entwicklung in den alten Ländern Baden UND WÜrTTEMBERG UND IN DEM NEUEN BUNDESLAND BADEN-WüRTTEMBERG 107-94 (1963).

24. "Civil servant" is an inadequate translation of the German Beamter, since it lacks certain attributes which place the Beamter in a special life-long relationship with the State (a public "company man"). There is, however, no better English equivalent. The Beamter has a long history in government as the heart of the administrative state. See generally $\mathrm{H}$. Hattenhauer, Geschichte des BeAmTentums (1980).

25. Technically speaking, criminal law and criminal procedure are areas in which, under a preemption analysis, either federal or state law may govern. GRUNDGESETz [GG] art. 74 (German Federal Constitution). Because the federal government has enacted laws, however, the states may not act. GG art. 72. Many areas of special administrative concern are open to both federal and state law, see GG art. 74, but general police law is left to the states since it is not among the exclusive or competing areas of jurisdiction. GG art. 70(I).

26. There are differences between the laws and police of the Federal Republic of Germany and its constituent states, but they are similar, much like the laws and institutions of the corresponding American jurisdictions are, if not more so. See generally E. Tschanett, Angleichungstendenzen im deutschen Länderpolizeirecht (1975) (dissertation). But see infra note 56. Given the historical predominance of Prussia and the role of its laws as the model for modern development, see infra notes 49-53 and accompanying text, much of the historical material herein draws on that model in lieu of the formal development in historical Baden and Württemberg. See E. Raible, supra note 23, for a non-lawyer's view of Baden-Württemberg history, and the sources cited in note 49 for legal analysis.

27. Statistisches Landesamt Baden-Württemberc, Gemeindestatistik 1980 (Hefr 1 ) 12 (1980) (state census office publication).

28. This comparison simply notes points in contrast with typical American jurisdictions, since one can no more speak of "American" than "German" police. For information comparing conditions for police of the various German federal states, although dated in some respects, the best immediate source is probably C. Helfer \& $W$. Siebel, Das Berufsbild des Polizeivollzugsbeamten: Gutachten im Auftrag der Ständigen Konferenz der InNenminister der Länder (1975) (government commissioned study), while the most easily available special source for BadenWürttemberg may be the police's own reference and training manual, LANDESPOLIzEISCHULE \& Fachiochschule für Polizei, Polizei-Handbuch für Baden-Württemberg (9th ed. 1980) (looseleaf, updated constantly). See also G. Endruweit, Struktur und Wandel der Polizei: ORGANISATIONS- UND BERUFSSOZIOLOGISCHE UNTERSUCHUNGeN ÜBER DIE POLIzei IN DER BUNDESREPUBLIK DEUTSCHLAND UND IN DEN USA (1979). 
are organized on a statewide level in a civil service organization. Policemen enjoy a lifelong career, and career incentives, including advancement possibilities, are significant. ${ }^{29}$ Officers typically enter the police force before the age of twenty and remain until their retirement at age sixty. Great pains are taken in the initial selection and training of police cadets. ${ }^{30}$ The cadets spend several years alternating between the police academy, training units, and probationary periods on the job until they are finally accepted into the police force as civil servants.

The police force is viewed as a professional organization, and there is very little lateral movement in or out of this organization. Within the police force, there is a pyramid structure consisting of three groups of ranks. ${ }^{31}$ Promotion within and between the groups is by merit. Policemen start as simple patrolmen and advance through the ranks, with advancement between groups awarded on a competitive basis. Usually, by the age of thirty it is clear whether an individual will advance beyond the first rank group to middle police management, and by the age of forty whether he will advance to the third rank group of senior police management. ${ }^{32}$ The most significant distinction at commencement of a police career and for several years thereafter is whether a policeman is trained and assigned to the uniformed police or to the detectives, which are separate organizations. ${ }^{33}$

Within Baden-Württemberg, the police work in every conceivable environment. The same state police which are responsible for Stuttgart, a heavily industrialized city comparable to regional population centers in the United States, are also responsible for policing large rural areas dotted with small towns. Uniformity of both police performance and standards across the entire

29. The statutory framework may be found chiefly in three sources: Landesbeamtengesetz of August 8, 1979, Baden-Württemberg GBI 398, as amended; Landeslaufbahnverordnung of February 15, 1971, Baden-Würtemberg $G B 127$, as amended; and, on the negative side, Landesdiziplinarordnung of August 1, 1962, Baden-Württemberg GBI 141, as amended. Federal law is also indirectly involved in the Rahmengesetz zur Vereinheitlichung des Beamtenrechts of January 3 , 1977, Bundesgesetzblatt [BGBl], Teil I 21, as amended.

30. See, e.g., Polizei-Führungsakademie Hiltrup, Auswahlverfahren für den Polizeivollzugsdienst-Möglichkeiten der Prognosen hinsichtlich der Bewährung im Beruf (March 22-26, 1976) (materials for seminar held for recruiting personnel at the national police academy); PolizeiFührungsakademie Hiltrup, Auswahlverfahren-Methoden und Erfahrungen (December 2-6, 1974) (materials for seminar held for recruiting personnel at the national police academy).

31. Mittlerer Dienst, gehobener Dienst and höherer Dienst. See infra note 34. The general legal requirements for each are set forth in the Landeslaufbahnverordnung of February 15, 1971, Baden-Wïrtemberg $\mathrm{GBl} 27$ as amended.

32. The Landeslaufbahnverordnung of February 15, 1971, Baden-Württemberg GBI 27, as amended, sets the outer age limits as a legal matter since promotion between rank groups is subject to maximum age restrictions, although in practice it may be clear well before the age of twenty-five who is on the "fast track" (based on police academy grades and early personnel evaluations).

33. German police sociologists have concentrated on the views of recruits and their alleged preference for detective service based on a feeling that the work is more varied and challenging. While at least one study has found higher initial promotion rates for detectives, 3 C. HELFER \& W. SiEbel, supra note 28, at 558-59, in the author's personal experience persons trained as detectives are relatively rare at the level of senior police management in charge of both uniform and detective units. This pattern may be the result of the detectives' relatively small number for early specializations, which takes them out of consideration for general line command positions. 
state is achieved by administrative supervision through the government hierarchy and by the common basic training in police academies ${ }^{34}$ for the various rank groups. Furthermore, there is constant personnel interchange that reflects a direct relationship between seniority of rank and professional mobility. While the lowest ranking group of officers tends quickly to reach and remain in a specific locality, middle and especially senior police management may be moved around within regional governmental districts and, in some cases, within the entire state. ${ }^{35}$

The unified structure of local and state government affects the policing environment in an unexpected fashion for the American lawyer accustomed to decentralization. ${ }^{36}$ The most significant source of local government power may be the senior local officials' ex officio status and power as state representatives for certain purposes. ${ }^{37}$

The executive branch of state government in Baden-Württemberg is structured on three levels. ${ }^{38}$ The highest level contains the ministries, and their statewide authority is based on the substantive areas for which they are responsible. The state is divided into four geographic districts (Regierungsbezirke), each of which contains an area the size of several large American counties. ${ }^{39}$ The intermediate level of the general state administration

34. In Baden-Württemberg, cadets seeking entry into the police at the level of patrolman (mittlerer Dienst) normally follow group tactics and basic training in the Bereitschaftspolizei by alternating practical experience while on probationary status and more theoretical schooling at the Landespolizeischule Freiburg. Candidates for the gehobener Dienst normally attend the Fachhochschule für Polizei, Villingen-Schwenningen (the curriculum of which is published as R. SCHULTE, Fachiochschulstudium für die Polizel in Baden-Württemberg (1980)). Candidates for the höherer Dienst attend the national police academy (Polizei-Führungsakademie Hiltrup). As used in this article the term "middle police management" typically refers to the middle-level rank group (gehobener Dienst) and "senior police management" typically refers to the highest-level rank group (höherer Dienst). Although the police chief in towns in more rural areas remains a member of the gehobener Dienst, he is also included in senior police management. Depending on the size of the town and local police contingent, other senior commanders may also be included. The police are currently implementing a policy to staff the most senior officer positions in rural areas with personnel from the höherer Dienst by replacement at retirement.

35. The articulated ground for this movement is to produce police management which is knowledgeable about policing in all environments. While mobility cannot be forced on police as civil servants, the ambitious officer sees this as part of the "fast track." Its chief effect is to prevent an ingrown atmosphere in many areas since senior police management and the middle level which is "on the way up" are rotated between jobs and police stations.

36. The home rule municipality is foreign to West Germany. Local municipal government does exist, but with sharply curtailed powers. See, e.g., art. $71(2)$ Verfassung Baden-Württemberg. The state government is responsible for many areas that the American lawyer customarily views as matters of local concern and control. See infra notes 38-41, 95-98 and accompanying text.

37. In Baden-Württemberg, this results from the senior officials' character as Polizeibehörde. See art. 71 (2) Verfassung Baden-WürtTemberg. The nature of the police power is such that its exercise is generally regulated by state police laws, such as POLG. This general regulation is displaced in specific instances by special laws such as those regulating emission of pollutants, contagious disease, etc. E.g., W. Keil, Die Subsidiarität des Polizeirechts: das Verhälınis zwischen allgemeinem Polizeirecht und besonderen gefahrabwehrenden Gesetzen (1972) (dissertation).

38. This statement ignores special agencies and similar entities, which are not material to this inquiry. The general structure is dictated by the Landesverwaltungsgesetz of April 1, 1976, BadenWürttemberg GBl. 325, as amended. The three-tier structure is shared by most of the German federal states. See generally H. MAURER, supra note 11, at 354-432.

39. Stuttgart is a special case insofar as its district includes the city itself as well as the normalsized administrative district. In practice, the city is split from the administrative district and is separately treated for most purposes. In this sense, there are five administrative units at the state level 
(Regierungspräsidium) functions at the district level, and it provides general governmental services for the geographic area (internal divisions are specialized by area of substantive responsibility)..$^{40}$ On the lowest rung, the state administration is represented in rural areas at the county level (in the Landesratsamt) and in urban areas at the municipality level (Kreisstädte). ${ }^{41}$ Organization of the state police parallels the three tiers of general state government. ${ }^{42}$

Representatives of the state government reach down to the localities through successive layers of the administration and are aware of local concerns. A more senior level of the administrative hierarchy always monitors local and regional representatives of the police and civilian departments. ${ }^{43}$ This practice is supported in law by the superior administrative level's powers of supervision and command (Aufsichtsbefugnisse and Weisungsbefugnisse) and the subordinate administrative level's corresponding duty to supply sufficient information (Unterrichtungspficht) so the control function can be meaningfully exercised. ${ }^{44}$

\section{B. Influence of Substantive Law Structures on Public Safety and Crimefighting Tasks of the Police}

A specific examination of the institutional influences affecting the police should begin with the legal basis of the organs of criminal justice and public order: the courts, prosecutors, police, and the secondary bureaucratic level of government. A basic caveat is in order: like those of other continental European countries, the West German law enforcement system conceives as separate the tasks of maintaining order and fighting crime. These tasks are governed by different bodies of statutory law. ${ }^{45}$ Depending on the law being enforced, the same governmental organ enjoys powers differing not only in degree but also in kind. ${ }^{46}$

(this is literally true for the police, since there are separate Landespotizeidirektionen in Stuttgart for the city and general administrative district). PoLG $\S 64$

40. The organizational chart for such an entity is reproduced in H. MAURER, supra note 11 , at 560. See also supra note 38 .

41. PolG \& 48.

42. See infra notes 95-100 and accompanying text.

43. This is a function of hierachical structure as a matter of hornbook law, but is normally regulated for public safety matters concerning civilian authorities by PoLG $\S \S 49-50$ and for the police by PoLG $\S \S 58-60$. For supervision of police in criminal investigations, see the sources cited in note 44 . The schematic diagrams in the Appendix illustrate the organization of supervision.

44. PoLG $\S \S 51,61-62$ (for police law). For criminal investigations involving the peculiar relationship between police and prosecutor, see notes 60-68 and accompanying text; Richtlinien für das Strafverfahren und das Bussgeldverfahren, effective January 1, 1977, [RIStBV], Allgemeine Verfügung des Justizministeriums of November 19, 1976, $\S 1,3$ and Anhang A. See also F. Görgen, Die organisationsrechtliche Stellung der Staatsanwaltschaft zu ihren Hilfsbeamten und zur Polizei (1973) (dissertation).

45. See supra note 25 and accompanying text; infra notes 50-68 and accompanying text.

46. In an extreme example, if a person is kidnapped and the police were to search an apartment for evidence of the kidnapper's identity, this repressive activity is subject to criminal procedure constraints and requirements for criminal search and seizure. If, however, the police believe that the kidnapped victim is in a certain area and conduct searches to free him, this preventive activity to preserve public safety is subject only to police law restraints on searches. The police law search is not subject to the same specificity requirements and may be conducted over a wide area (for 
Modern police derive the substantive scope of their powers from the institution-the public prosecutor or civilian state authorities-under whose authority, and subject to whose directives, they act. Thus, a practical measure of police discretion at the institutional level is the extent to which the police do not function under direct control of the governmental entity from which their authority is derived. In practice, there is an observable migration of decisional authority to police at this institutional level. ${ }^{47}$

The deep historical roots of the governmental institutions are important to an understanding of the modern crimefighting/peacekeeping dichotomy. The jurisdictional lines of this dichotomy are the result of historical institutions-inquisitorial courts and absolutist governments-against which modern West German laws are a reaction. ${ }^{48}$ A little history is quite helpful in explaining this apparently counterintuitive dichotomy to the American lawyer, and its internalization is necessary to a full understanding of how German police analyze their legal options in a law enforcement context.

\section{Historical Peacekeeping Function and the Public Good. The development of} the law of public order serves as the basis of the modern German concept of "police." 49 During the supremacy of absolutist rule prior to the second half of the nineteenth century, "police" referred to the entire governmental administration. ${ }^{50}$ Its power over subjects was absolute since officials acted as personal agents of the monarch.

example, all apartments in a building where police believe a victim is held). See, e.g., R. BELz, Polizeigesetz für Baden-WürtTemberg mit ERLÄUterungen UNd ergäNZenden Vorschriften 143-44 (2d ed. 1979) (comments 11-13 to PoLG § 25(2)2(3)). This type of distinction, and the tension created if the different underlying tasks are not clearly separated, is evident from time to time in the American caselaw's handling of issues relating to regulatory searches (such as the warrant requirement in the context of building inspections or OSHA violation inspections).

47. See infra notes 80-81, 111-16 and accompanying text.

48. See sources cited infra note 61; see also infra notes 49-65 and accompanying text.

49. H. Maier, Die ältere deutsche Staats- und Verwaltungslehre (2d ed. 1980), traces the development in detail. This "police state" or "welfare state" (Polizeistaat; Wohlfahrtsstaat) exercised absolute power over the life of the subject; the Executive's own opinion was irrefutable regarding what served both the State's well-being and that of the individual. See also V. Götz, Allgemeines Polizei- Und Ordnungsrecht 11-16 (6th ed. 1980). From its early modern development period until the beginning of the nineteenth century, the entire state administration was considered to be the "police," as an extension of the state's own power. See note 67 and sources cited therein for the historical interplay between the power of the state and administrative competence. As the modern state was organized as an administrative state, the police power was institutionalized in the branches of bureaucracy responsible for certain subject matter. There was no unitary "police force" in the American sense, but rather, in a technical sense, "police" for enforcing construction ordinances, for enforcing occupational laws, and so forth.

The development is traced in Prussia, the politically crucial north German state which eventually became the center of the German Empire and which was the equivalent of a leading jurisdiction. While other German states, such as the then separate states of Baden and Württemberg have separate but related histories see, e.g., sources cited supra note 23; sources cited in V. GöTz, supra at $12 ; \mathrm{H}$. Röss, Generalklausel und Spezialermächtigung nach baden-württembergischem Polizeirecht (1962) (dissertation), Prussian development should loosely be considered as constitutional development. Specifically Prussian developments may be best followed in K. Wolzendorff, Der Polizeigedanke Des modernen StaAts: ein Versuch zUR allgemeinen Verwaltungslehre UNTER besonderer Berücksichtigung der Entwicklung in Preussen (1918 \& photo. reprint 1964).

50. See H. Maler, supra note 49, at 92-104. From the historical perspective, the meaning of "police" is significant for the social change underlying the movement from feudal to modern state. Id. 
Foreshadowing the modern state, during the Enlightenment period the monarchy abandoned the absolutist idea of the ruler as the center of the state and replaced it with the new idea that a monarch is the first servant of the state, a trustee for the people subject to the rule of law. ${ }^{51}$ This reform conviction evidenced itself in the Prussian General State Law, Allgemeine Landesrecht, of 1794, the theoretical background for the organization of a modern administrative state. ${ }^{52}$

The most important element of the Prussian General State Law for these purposes is contained in Section 10, II 17, defining the new rule of the German concept of "police" (which includes the general and civil administration): "The police are charged with the duty to take such measures as are necessary to maintain public peace, safety, and order and to protect the public or its individual members from present danger." 53 This legislation is crucial, forming the model and point of departure for modern German police law (Polizeirecht), which is simultaneously the ancestor of and part of modern German administrative law. Police law is controlled by discretionary principles in its application (Opportunitätsprinzip). ${ }^{54}$ It is subject, however, to the pre-

51. H. Conrad, Die geistigen Grundlagen des Allgemeinen Landrechts für die preussischen StaAten von 1794, at 19-24 (1958).

52. Id. See generally K. WolzendorfF, supra note 49. The nascent departure of the Prussian police law from the Polizeistaat or Wohlfahrtsstaat suffered a setback in the reactionary period following the French Revolution. Through regulations and legislation in 1808 and 1850 , the power of the state was indirectly reextended to cover the individual's welfare, in contradiction to the 1794 legislation restricting protection from danger and maintenance of public order. See V. Götz, supra note 49, at 11-16. The more restrictive view of 1794 again found acceptance in the late nineteenth century in the Kreuzberger Judgment. Id. at 13-14. But see P. Preu, Polizeibegriff und StaAtszwecklemre 315-19 (1983).

53. Translation of "Die nöthigen Anstalten zur Erhaltung der öffentlichen Ruhe, Sicherheit und Ordnung und zur Abwendung der dem Publiko, oder einzelnen Mitgliedern desselben bevorstehenden Gefahr zu treffen, ist das Amt der Polizei." This rule is paralleled in present day PoLG $\S 1(1)$ as

Die Polizei hat die Aufgabe, von dem Einzelnen und dem Gemeinwesen Gefahren abzuwehren, durch die die öffentliche Sicherheit oder Ordnung bedroht wird, und Störungen der öffentlichen Sicherheit oder Ordnung zu beseitigen, soweit es im öffentlichen Interesse geboten ist. Sie hat insbesondere die verfassungsmässige Ordnung zu schützen und die ungehinderte Ausubüng der staatsbürgerlichen Rechte zu gewährleisten.

This section can be translated,

The police has the task of protecting individuals and the community from dangers through which public safety or order are threatened and of rectifying disturbances of public safety or order insofar as is required by the public interest. In particular, the police is charged with protection of the constitutional order and is bound to secure the unhindered exercise of citizens' rights.

("Police," in the sense of the Polizeigesetz, encompasses both the institutional and the substantive concepts of police. See infra note 56.)

Disregarding for the moment special statements affirming protection of citizens' rights from third party encroachment, the modern form does not incorporate substantial changes. In fact, the modern police law statute tends to include only refinements to the original concept of the statute. More than anything else, this modern formulation is the codification of caselaw explications of older statutes in nonarchaic language. There is, however, a significant distinction on the political side, as political disorders were considered public disturbances under older law.

54. E.g., 1 K. VoGel, supra note 18, at 135-72. In fact, German law itself recognizes so many exceptions in the criminal law area, see J. BaUmann, GrundBegriffe UNd Verfahrensprinzipien des STRAFPROZESSRECHTS 49-56 (3d ed. 1979), that some academic commentators think the exceptions 


\section{viously discussed requirement of general administrative law that discretion be "well-tempered." 55}

In the twentieth century, administrative agencies of the state were separated from the enforcement arm of the police force. ${ }^{56}$ As the general state

have overwhelmed the rule, e.g., Schröder, Legalitäts- und Opportunitätsprinzip heute, in Festschrift Für Karl Peters $411-27$ (1974). From an American perspective, however, the rule still predominates.

55. E.g., I K. VoGEL, supra note 18, at 135-72. See generally supra notes 11-16 and accompanying text.

56. The specific tasks of suppressing street crime and the maintaining public order led to the creation of uniformed police (Sicherheitspolizei or, in the modern terminology, Schutzpolizei) in a number of German states around 1800 . The role of this particular police was prospective: to keep the peace and prevent crime. The relatively modern investigative police (Kriminalpolizei), specializing in the retrospective analysis of committed crimes, was only gradually introduced in the second half of the nineteenth century, at which time it was separated organizationally from the peacekeeping force and put under the direction of the prosecutor to assist in his work as "auxiliaries." See infra notes 65. 68 and accompanying text. As an organizational matter, the Schulzpolizei has taken over investigations of petty crimes. For that reason, detectives work only on more substantial matters in the modern police.

The development of law enforcement agencies must be envisioned as a parallel to the changing ideas of the state's power to police, the concept of administrative agencies as "police," and the coincident change from the older inquisitorial courts to the modern continental criminal procedure. See supra notes 49,52 and accompanying text; infra notes 60-61 and accompanying text. The last days of the inquisitorial courts and the rise of a police force overlapped. In Berlin, on the leading edge of police development, the majority of the investigative duties of the inquisitorial court in crime fighting were transferred to the nascent investigative branch of the police force. Only the introduction of the prosecutor in the reform system several decades later brought supervision to the police who were his "auxiliaries." See generally sources cited infra note 60. This reform of the equivalent of the American pretrial investigation was necessitated in part by the misbehavior of the police in the intervening period, as well as by the dissatisfaction with the inquisitorial procedure. See generally infra notes 60-61 and sources cited therein. The tendency of police to overreach and to disregard the balance of the law in criminal investigations was to be checked by a prosecutor whose quasi-judicial role and duties set him apart from a comparable American figure. The supervision of the remainder of the police force was undertaken in part by the general state government (the peacekeeping function), and in part by those specific agencies whose "police power" regulations were implicated (health ordinances, building codes, and so forth, to the full extent of the power to police).

The final stage in German police development followed the collapse of the Third Reich, during which the police forces of German states had been nationalized, centralized, and brutally employed against opponents of national socialism. The victorious allies dismantled the existing police apparatus and attempted to decentralize police forces from the national to the local levels with the recreation of federal states, as a response to the perceived dangers of a totalitarian state. This process has now largely been reversed, see supra note 23 , and present German police forces are centrally organized at the state level. A more lasting change was achieved in the postwar reorganization of the organs still referred to as police, according to the tradition that the entire government apparatus was the "police." See supra note 49 . Many specific agencies with regulatory tasks analogous to the American "police power" were separated completely from the older structure as independent agencies. The theoretical depth and characterization of this separation is one of the actively debated issues that distinguish the German jurisdictions. The splits between jurisdictions, see supra note 26; H. Scupin, Die Entwicklung des Polizeibegriffs und seine Verwendung in den neuen deutschen Polizeigesetzen (1970) (dissertation), are based in an older north-south division of jurisdictions aggravated by Entpolizeilichung reforms mandated by the occupation forces after World War II, but the argument (while politically charged) affects practice very little. The minority jurisdictions, most recently represented chiefly by Bavaria, have adopted laws in which the term "police" designates only the law enforcement agency familiar to Americans. This action is not surprising, since Bavaria was in the American zone immediately following the war. The traditional viewpoint (substantially adhered to in Baden-Württemberg, id. at 135-38) largely follows the older Prussian model that "police" is substantively synonymous in scope with the German equivalent of "police power," and it treats designation of enforcement organs as a jurisdictional problem of decisional competence. A third group of jurisdictions effectively employs the Prussian model but more clearly separates the civilian agencies with primary decisional competence in public safety matters (Ordnungsbehörden). See generally W. MarTENS, 
administration, the state agencies are "police authorities" (Polizeibehörde), ${ }^{57}$ but are institutionally separate (as civilian entities) from the law enforcement agencies (Vollzugspolizei) ${ }^{58}$ empowered to execute their directives. ${ }^{59}$

\title{
2. Historical Crimefighting Function. The modern German institutions of
} courts and prosecutors ${ }^{60}$ were created at the beginning of the nineteenth century essentially by splitting the office of inquisitorial judge into an accusatory prosecution element and an impartial adjudicatory element, ${ }^{61}$ The prosecutor lost the power of an inquisitorial judge to convict the accused, and was

\begin{abstract}
Wandlungen des Polizeibegriffs, Generalklausel und Spezialermächtigungen, die Generalermächtigung zur Gefahrenabwehr, POlizeipflichtige Personen (8th ed. 1977); H. Scupin supra; E. Tschanett, supra note 26 . The doctrinal categories employed in discussion are commonly the substantive, institutional, and formal police concepts (materielle, institutionelle, and formelle Polizeibegriffe). What is in a name? The political direction of the technical debate is that, by adhering to older Prussian categories, law enforcement agencies enjoy powers of civil government, which is disturbing to Germans for historical reasons related to the exercise of state power. In practice, the categories of discussion appear not to make a substantial difference in how law enforcement agencies interface with the civilian administration. Through adoption of the Musterentwurf, see supra note 2, or a substantial part of its provisions, the state police laws (including Bavaria's) may be converging now more than ever.
\end{abstract}

57. E.g., PoLG §§ 47-51.

58. E.g., PoLG $\S \S 56-62$.

59. The more modern view in German police law attempts to dispose entirely with a separate substantive concept for the police; however, for the American reader the underlying structural separation of the police tasks (maintenance of order and the suppression of crime) is what remains important. See supra note 56.

60. From the Renaissance until the late Enlightenment, the law enforcement function of today's German prosecutors and criminal courts was chiefly performed by inquisitorial courts. See J. Langbein, Prosecuting Crime in the Renaissance (1974). Seventeenth and eighteenth century German legal thought did have a substantive concept of "police." Under that concept, however, the entire administrative apparatus of the state was viewed as an extension of the absolutist ruler. See supra note 49 and sources cited therein. The inquisitorial court largely conducted its own investigation into criminal matters with the assistance of a few bailiffs. Investigations were commonly limited to extracting a confession under torture, since there were no organized police to examine witnesses not under the direct control of the court. See Langbein, Torture and Plea Bargaining, 46 U. CHI. L. Rev. 3 (1978). See also F. GörGEN, supra note 44, at 35-60, for a more general historical inquiry about police-judge and police-prosecutor relations in the eighteenth and nineteenth century period. A more polarized historical picture of the relationship is presented by A. WAGNER, Der KAMPF Der Justiz Gegen die Verwaltung in Preussen (1936). Uniformed regular police only developed toward the end of the eighteenth century in cities such as Berlin, see generally W. Obenaus, Die ENTWicklung der preussischen Sicherheitspolizei bis zUM ENDE der ReakTionszeit (1940), although their beginnings may be traced back to the Landreiter and city watches.

61. E.g., H. Zachariä, Die Gebrechen und die Reform des deutschen Strafverfahrens, DARGESTELLT AUF DER BASIS EINER CONSEQUENTEN ENTWICKLUNG DES INQUISITORISCHEN UND DES accusatorischen Prinzips (1846); see also E. Carsten, Die Geschichte der Staatsanwaltschaft in Deutschland bis zur Gegenwart: Ein Beitrag zur Reform des Strafprozesses (1932) (dissertation); K. Elling, Die Einführung der Staatsanwaltschaft in Deutschland, ein Beitrag zur Geschichte des Strafprozesses (1911) (dissertation). This reform was instituted gradually in a number of German states prior to Unification and reached its conclusion in the 1877 Reich Code of Criminal Procedure, which is still in force in West Germany as federal law, albeit in much amended form. The prosecutor received a monopoly on the pursuit and prosecution of crime (Anklagemonopol); the investigative and charging authority of the inquisitorial judge was denied to the new judiciary, who nonetheless remained distinguishable from their common law brethren. Although his pretrial investigative role was largely lost to the prosecutor, the new German judge retained the chief forensic role at trial as well as an independent duty to clarify the events (Aufklärungspficht) underlying the prosecution; he is a more active character than the Anglo-American judge serving as "referee" in an adversarial trial. For a current English language treatment, see J. Langbein, Comparative Criminal Procedure: Germany (1977). 
assigned as a counterweight to his charging monopoly the duty to investigate and prosecute all suitable crimes (Legalitätsprinzip or the principle of compulsory prosecution $\left.{ }^{62}\right) .{ }^{63}$ The prosecutor in the new system retained responsibility for the physical investigation of suspected crimes. ${ }^{64}$ The uniformed police had no direct investigative power or duty comparable to that of the prosecutor. ${ }^{65}$

The subjugation of the police to the office of the prosecutor is crucial to an understanding of the German public law concept of the police's role in crimefighting. The Code of Criminal Procedure, empowering investigative measures such as searches, seizures, and arrests, strikes a compromise regarding the activities of police. It directs that "auxiliaries of the prosecutor" (Hilfsbeamte der Staatsanwaltschaft ${ }^{66}$ ) act under the prosecution's direction in investigating crimes. As such, the auxiliaries are subject to the Legalitätsprinzip, which in theory is a denial of discretion. ${ }^{67}$ Historically, who

62. This principle has been treated in English at length in connection with the plea bargainingprosecutor's discretion debate. See, e.g., J. LANGBEIN, supra note 61, at 87-109; Jescheck, The Discretionary Powers of the Prosecuting Altorney in Western Germany, 18 AM. J. Comp. L. 508 (1970); Goldstein \& Marcus, The Myth of Judicial Supervision in Three "Inquisitional" Systems: France, Italy and Germany, 87 YALE L.J. 240 (1977); Langbein \& Weinreb, Continental Criminal Procedure: "Myth" and Reality, 87 YAL.E L.J. 1549 (1978), and sources cited therein. While treated as hornbook law, e.g., J. BAUmaNN, supra note 54, at 47-56, the principle is still the subject of discussion and challenge in Germany. See, e.g., T. Weigend, Anklagepflicht und Ermessen: die Stellung des Staatsanwalts zwischen Legalitäts- und Opportunitätsprinzip nach deutschem und amerikanischem Recht (1978) (dissertation); Schröder, supra note 54, at 411-27.

63. To fulfill this function the prosecutor assembled the dossier (investigative and litigation file), on the basis of which the judge would conduct the open court portion of the trial. The American reader might best visualize this in one of several criminal procedure handbooks explaining the conduct of a criminal case by exemplary use of a file. E.g., G. Schäfer, Die Praxis des Strafverfahrens an Hand einer AkTe: das Verfahren in erster Instanz (2d ed. 1980). In German legal thought the "trial" extends from the very beginning of the prosecutor's investigation (with three stages as a matter of hornbook law, the Vor-, Zwischen-, and Hauptverfahren), and in substance it is often concluded by the time proceedings in open court are commenced. The public trial is preserved for both political and legal doctrinal reasons, but the American lawyer should recall that the German judge has a full litigation file before him as a finder of fact while proceedings in open court take place.

64. The prosecutor still retains responsibility, see $\operatorname{RISTBV} \S \S 1,3(\mathrm{I})$, although in practice he relies on police work. E.g., W. Steffen, ANAlyse POlizeilicher ERmitTlungstätigkeit aus der Sicht des SPÄteren STRafVerfahrens 267-68 (1976).

65. Instead, the 1877 Reich Code of Criminal Procedure assigned powers and duties to the prosecutor and in some graver cases to an independent investigating judge. The office of the investigative judge (borrowed from French law) has since been abolished. The prosecutor is now solely responsible for criminal investigations. But see infra note 118 .

66. Who shall be such an officer is a question relegated to state law by section 152 of the Gerichtsverfassungsgesetz of January 27, 1877, Reichsgesetzblatt [RGBI] 41, as amended. Cadets and senior police management (above a certain rank) are excluded by law from the prosecutor's auxiliaries. The heart of the compromise left open the choice whether the prosecution would form its own team of investigators to prepare cases, or whether it would adopt the nascent police as auxiliaries. See supra note 56.

67. Much of American law that covers traffic or minor offenses is technically decriminalized in West Germany, however, and infractions are subject to discretionary pursuit by adminstrative authorities and prosecutors. Historically, the German substantive law forbidding certain acts was contained in two bodies of law: criminal codes and police offenses codes. The two bodies of law were grounded in different historical jurisdictions (police law and the jurisdiction of police law courts rested with local princes, while criminal law was a national matter for the monarch's courts) and so varied at different times in different places. However, in general criminal offenses were more serious 
these "auxiliaries" would be was left to state law, but the police were chosen. Currently, police officers acting as prosecutorial auxiliaries are institutionally but not theoretically separate from the prosecutor when acting under his authority but not his direct command. 68

\section{IV}

\section{Police Accountability and Interplay Within the Administrative Hierarchy}

Depending upon whether he acts in a crimefighting or peacekeeping capacity, the German policeman faces situations in which either the law recognizes no discretion or the law expressly recognizes discretion but limits it to "well-tempered" discretion. Dividing law enforcement activities into peacekeeping and crimefighting aspects also channels supervising authority. The exercise of discretion may be found on two levels of analysis of the internal control function.

At an institutional level, police management has attempted to establish the police force as independent of the civilian administration and the prosecutor's office. $^{69}$ Further, by ministerial directive, personnel at the senior level of police management hold offices in the intermediate levels of the civilian police authorities, ${ }^{70}$ thus breaching the strict separation of police and civil administration in the review function. ${ }^{71}$

On the operational level of policemen on the beat, empirical studies document their tendency to find a policing role in peacekeeping more often than in

violations. The police offenses were theoretically similar to both modern American minor offenses and administrative health and safety regulations which punish violations of laws promulgated under the "police power." See, e.g., W. von der Heyde, Polizei-Strafgewalt in den Königlich Preussischen StaAten, oder auch Darstellung des Verhältnisses der Polizeigewalt zu der Justizgewalt, der Ausübung des Polizei-Strafrechts, und der Handlungen, welche zu den Polizei-Straffällen gehören (1837). These old German police offenses, however, exceed the scope of American administrative offenses, since the then current German concept of "police" exceeded the American idea of "police power." See supra note 49; P. PreU, supra note 52. The German statutory developments are best followed in H. MATtes, UNTERSuCHUNGen zur LEHRE VON den Ordungswidrigkeiten: Erster Halbband, Geschichte und Rechtsvergleichung 5-182 (1977). The scope of German police offenses included not only the typical American elements of health, safety, and welfare in regulating industry, etc., but also the lower level of criminal offense. The police power enactment lives on in modern law in the Polizeiverordnungen, PoLG $\$ \$ 10.18 \mathrm{a}$, a technical violation of the separation of powers doctrine touching on our theme in the question of who makes law.

68. The legal tension inherent in this "neither fish nor fowl" status is best captured in F. GöRGEN, supra note 44. See also infra note 118.

69. See infra notes 78-81, 111-16 and accompanying text. The organizational subjugation of police to prosecutors has been a particular sore point with police for a number of years, as witnessed by numerous articles in professional journals catering to police. See, e.g., W. STEFfen, supra note 64 , at 52-53. Police dissatisfaction may be beside the point in the criminal area, since in modern criminal trial handbooks (often written by and for younger judges and prosecutors as introductions to practice) the independence of police is accepted as a fact. E.g., E. Schlüchter, Das Strafverfahren 66 (1981). Some commentators, while acknowledging this fact, are less happy with this state of affairs. E.g., G. SCHÄFER, supra note 63, at 155. A review of the schematic diagrams in the Appendix, entitled The Organization of the Police in Baden-Württemberg and Police Supervision in Baden-Württemberg, is recommended as an aid to visualizing the interrelation and formal paths of interaction between police authorities and the police force.

70. See infra note 112 and accompanying text.

71. See infra note 113 and accompanying text. 
crimefighting. ${ }^{72}$ By treating crimefighting functions as peacekeeping matters, policemen exchange the supervision of the prosecutor for the supervision of civilian police authorities. Through the establishment of the law enforcement agency's institutional independence and the sharing of senior personnel with civilian authorities, however, a certain amount of the civilian authorities' supervision is already exchanged for internal supervision within the law enforcement agency.

\section{A. Crimefighting: The Public Prosecutor and Police-Accountability for Conduct of the Criminal Investigation and Trial}

The modern German criminal investigation and trial is influenced by three institutions: the police, the prosecutor, and the court. In theory, discretion is squeezed out of the criminal justice system by the Legalitätsprinzip, or at least is reserved primarily in the hands of the judiciary. Police involvement as prosecutorial auxiliaries is already a tertiary role. Yet, despite their theoretical subsidiary status, the police are in practical control of the pretrial investigation. This fact raises immediate questions about discretion concerns in two areas: (1) whether the Legalitätsprinzip is applied consequently (and whether crimes are charged); and (2) how investigations are conducted.

The office of the German public prosecutor and the principle of compulsory prosecution have attracted American academic interest in connection with the plea bargaining-prosecutorial discretion controversy. ${ }^{73}$ Concerns of ancillary prosecutorial discretion and the statewide hierarchical organization of the prosecutorial corps ${ }^{74}$ impinge upon a discussion of police discretion, yet the limited scope of this article permits only reference to this literature instead of its reexamination in detail. The American literature's discussions of the German prosecutor and his role in crimefighting, however, suffer from an interpretive bias imposed by implicit comparison to the American prosecutor. The nature and role of participants in the pretrial investigatory phase are sometimes lost in this treatment.

The German trial may be viewed as coextensive with the criminal investigation, which is treated as one of the trial stages as a matter of hornbook law. ${ }^{75}$ The Legalitätsprinzip compels commencement of proceedings; however, the trial begins to take shape when the equivalent of a probable cause determination is made. It unfolds during the investigation under the judicial branch, since the prosecutor is institutionally descended from a judge ${ }^{76}$ and is

72. See, e.g., J. Feest \& E. Bl.ankenburg, Die Definitionsmacht der Polizei: Strategien der Strafverfolgung und soziale Selektion 86-93, 132-33 (1972).

73. See the English language sources cited in note 62 for an entry into the literature.

74. E.g., E. SChlüChter, supra note 69, at 45-65. See also sources cited infra note 82.

75. See supra note 63 . The terms Vorverfahren and Ermittlungsverfahren are basically interchangeable, although the former places the criminal investigation in perspective as part of a broader whole while the latter focuses on function.

76. See supra notes 61-65 and accompanying text. 
currently considered an officer of the court with broad investigative powers. In practice, the police exercise these powers.

The prosecutor remains responsible for the early stages of the "trial," but due to high crime rates and personnel shortages he is no longer in clear control of the investigative portion. ${ }^{77}$ The police apprehend offenders, develop case files and forward them to the prosecutor when the criminal information (Anklage) is to be filed. ${ }^{78}$ The chief role of a prosecutor is now in the actual trial, its immediate preparation, and control of the charging decision. Because of limited manpower, the public prosecutor's office can exercise meaningful investigative supervision only regarding serious offenses, and then only by giving the police general directives concerning who is to be interrogated, what witnesses should supply written statements, and so forth. ${ }^{79}$

Current scholarship has called into question police support for the principle of compulsory prosecution. ${ }^{80}$ The prosecutor can only act on the basis of evidence resulting from investigations that he no longer actually conducts. Thus, the prosecutor will fail to bring charges for lack of evidence to the extent that police neglect to investigate crimes they regard as less serious or less promising in terms of conviction (which may be a rational decision to allocate limited manpower resources). ${ }^{81}$

Prosecutors and police management stress the effect of potential judicial and administrative review as an incentive in their pursuit of investigations. The Legalitätsprinzip does not require charging where no conviction may be obtained due to lack of evidence, but a decision by the prosecutor to close any investigation is reviewable by his superiors at both the local and appellate court levels. ${ }^{82}$ As in the general administration, the affected citizen may make a formal administrative complaint. ${ }^{83}$ The prosecutorial hierarchy's decision is subject to judicial review. Also, certain individuals have standing to challenge the failure of the prosecutor (and indirectly the police) to pursue alleged offenses. The equivalent of a mandamus action (Klageerzwingungsverfahren) lies to challenge the failure of the prosecutor to pursue an alleged infraction, ${ }^{84}$ while a variety of offenses related to obstruction of justice are applicable to both police and prosecutor. ${ }^{85}$ Within these parameters, neglecting the

77. This proposition assumes that the prosecutor was at some time in full control, a historical position on which commentators differ. See, e.g., sources cited supra notes 60-61.

78. See supra note 69.

79. RISTBV $\S 3(\mathrm{I}), 3(\mathrm{II})$; see also W. STEFfen, supra note 64 , at 267-68

80. See infra notes $124-55$ and accompanying text.

81. E.g., W. STEFFEN, supra note 64, at 259-89, 294.

82. RiSTBV $\S \S 88-105$. The legal aspects of the prosecutorial structure are concisely presented in E. SCHLÜChter, supra note 69, at 45-65, while the empirical functioning of the prosecutor's office as a part of the criminal justice system is best captured by E. Blankenburg, K. Sessar \& W. Steffen, Die Staatsanwaltschaft im Prozess strafrechtlicher Sozialkontrolle (1978). For the reader familiar with the substantive law there is a "how to" manual for law clerks and new prosecutors providing insight into day to day operations, F. Kunigk, Die staatsanwaltschaftliche TätigkeIt: EINFÜHRUNG Mit MUSTERVERFüGUNGEN (2d ed. 1978).

83. See infra note 109 and accompanying text.

84. Strafprozessordnung STPO \$ 172; RiStBV § 105

85. For example, Strafuereitelung im Amt or Rechtsbeugung and potentially other of the so-called Amsverbrechen. 
investigation/trial is itself a violation of the law.

Beyond the Legalitätsprinzip, the conduct of criminal investigations by German police involves choices among courses of conduct raising concerns similar to those addressed by the fourth, fifth, and sixth amendments to the United States Constitution. ${ }^{86}$ The contours of threshold determinations for police measures (searches, seizures, and arrests) are beyond the scope of this article although the constellations of probable cause, subsidiary conditions, and the permitted extent of such measures differ significantly from those of the United States. They are governed by the Code of Criminal Procedure, which assigns responsibility for criminal investigations to the public prosecutor, theoretically reserving for the judge the power to order arrests, searches, and seizures. ${ }^{87}$ Yet, the power to undertake these actions in criminal investigations is a practical subject of police discretion insofar as police make the operative decisions. ${ }^{88}$

The clearest analogy to the German supervision requirement may be the American warrant requirement, by which the power to make certain decisions is denied to the police. The Code of Criminal Procedure empowers varying combinations of judges, prosecutors, and prosecutors' auxiliaries (police) to order searches, seizures, and arrests under given circumstances. ${ }^{89}$ In general, the Code of Criminal Procedure presupposes an image of the criminal investigation in which the judge dominates, the prosecutor is empowered to act under "exigent circumstances," and the police may act for the prosecutor in a more restricted set of cases. In both the Code of Criminal Procedure and state police laws, various provisions allow law enforcement officers to act

86. The values and protected rights of the fourth and fifth amendments are contained in several articles of the current German Federal Constitution: Articles 1 and 2(1) of the GG provide protection of "human dignity" and "personality," roughly corresponding to the diverse interests protected by American "privacy"; Article 2(2) of the GG protects the individual in his freedom and bodily integrity, corresponding to American searches and seizures of the person; Article 10 of the GG protects the confidentiality of post and telecommunications, corresponding to the American wire-tapping and postal seizure jurisprudence; and article 13 of the GG protects the sanctity of the dwelling, corresponding roughly to the classic arena of the exclusionary rule. These rights may be reasonably restricted but not fully impaired by laws. GG art. 19(2). The substantive law of criminal justice (repressive) is federal, while state law governs the preventive area of police power and the maintenance of order (including matters which Americans would consider criminal law enforcement), see supra notes 25,67 .

This more specific enumeration of protected rights is merely a result of the German Constitution's late date, insofar as the individual rights provisions were, at least superficially, influenced by Anglo-American models following World War II. Significantly, however, the majority of Code of Criminal Procedure provisions enabling searches and seizures of the person and property predate the current Constitution and therefore are deemed constitutionalized, see supra note 5 . The older provisions have their source in the 1877 Reich Code of Criminal Procedure, while significant inroads have been made recently due to social pressure to crack down on terrorism (e.g., the lex BaaderMeinhoff), see supra note 2.

87. The classical characterization of the prosecutor and his pre-trial role is "Herr des Ermittlungsverfahrens." His powers to undertake various specific investigative acts are set forth in the statutes cited in note 89 .

88. Furthermore, the capacity to choose to act under one or another set of substantive powers of differing extent is a powerful device. It in effect shifts the watchdog function of administrative review among different supervising agencies. See infra note 116 and accompanying text.

89. See, e.g., SтPO $\S \S 81 \mathrm{a}, 98,100 \mathrm{~b}, 105,111 \mathrm{e}, 125,126 \mathrm{a}, 127$. 
without prior instruction when they encounter situations on the street in the presence of Gefahr in Verzug (danger in delay) if time does not allow them to consult with civilian police authorities or the judge/public prosecutor. This exigent circumstances exception is broadly interpreted.90

The exception is commonly articulated in criminal procedure as follows: "Danger in delay exists, whenever the [investigative measure's] success would be endangered by the delay which would arise, if the responsible [judge] were contacted." 91 The exception is formulated similarly for police law: "Danger in delay exists, when in the absence of immediate action it is probable that damage will result such that the success of required measures would be reduced or impeded." 92

Procedural difficulties hamper a challenge to a policeman's claim that delay would endanger results. More important for the challenger, however, is the legal standard of review: whether in the subjective opinion of the policeman such danger existed. ${ }^{93}$ Practically speaking, unless an officer acts in an openly arbitrary manner his true subjective conviction is a matter of speculation. ${ }^{94}$ The police make a decision theoretically reserved to the

90. German law also undercuts the content of "danger in delay" in the investigative area by failing to require positive steps to prevent the loss or disappearance of evidence before exigent circumstances are recognized. For example, German law would not commonly recognize the necessity of isolating and guarding a dwelling while a judicial warrant is applied for, as was suggested in Vale v. Louisiana, 399 U.S. 30 (1970). At the same time, certain constitutional rights of premier importance may interact with facially neutral rules of constitutional law (Verhältnismässigkeitsprinzip, see supra notes 17-18 and accompanying text) automatically to produce danger in delay. For example, the relatively high value placed on liberty may render unlawful substantial detention (the deprivation of personal freedom, including temporary police custody which can be less intrusive than either formal arrest or incarceration) when otherwise necessary to the protection of property interests. Domiciliary privacy is protected by requiring police to obtain the equivalent of a search warrant. Moreover, this rule extends not only to the person and immediate surroundings of the accused, but also to searches of his dwelling miles away on the ground that, if released, he could destroy the evidence concealed there. For instance, a suspect picked up in a parking garage on suspicion of theft from automobiles may be taken directly to his dwelling as part of a search for contraband. Unless and until the suspect objects, the police would see a greater evil in detaining the suspect in anticipation of a warrant (liberty interest) than searching without a warrant (property interest).

91. E.g., T. Kleinknecht, Strafprozessordnung 257 (34th ed. 1979) (comment 3 to StPO $\S 98$ ). Translation of: "Gefahr im Verzug .. . besteht, wenn die richterliche Anordnung nicht eingeholt werden kann, ohne dass der Zweck der Massnahme gefährdet wird . . . ."

92. R. BELz, supra note 46, at 34 (comment 7 to PolG \& 2). Translation of: "Gefahr im Verzug besteht, wenn ohne sofortiges Eingreifen mit Wahrscheinlichkeit ein Schaden eintreten und damit der Erfolg der erforderlichen Massnahme beeinträchtigt oder vereitelt würde."

93. E.g., T. KLeinknecht, supra note 91 , at 275 (comment 3 to STPO $\$ 95$ ). This is the majority view, although it is subject to challenge. See also infra note 94; supra note 20.

94. Two empirical studies have attempted to quantify the shift of decisional competence to the police through exigent circumstances exceptions. Both studies are subject to the caveat that they dealt with limited samples of reported instances of police measures, and should therefore be viewed as tentative.

U. Nelles, Kompetenzen und Ausnahmekompetenzen in der Strafprozessordnung: zur organisationsrechtlichen Funktion des Begriffs "Gefahr in Verzug" im Strafverfahrensrecht (1980) (dissertation) (a Nordrhein-Westfalen study sampling the 1971 cases of three prosecutors' offices: Bochum, Duisburg, and Cologne), found that police acted without judicial supervision in criminal investigations in ordering searches of persons or property in $89.77 \%$ to $93.19 \%$ of the examined searches (Durchsuchungen), id. at 215. The proportion of police-ordered searches of the person raises the average, since the figures for property searches alone indicate that between $84.21 \%$ and $89.41 \%$ of those searches are ordered by the police. Id. at 220 . (Technically speaking, the study deals with 
German prosecutor or judge. At this level of activity, the police may be functionally independent although still subject to substantive law constraints.

\section{B. Maintenance of Order: Interlocks and Control of the Police by the Civilian Administration}

The coupled powers of review and command in police law require more detailed examination. The chain of command is embedded in the civil and law enforcement administrative hierarchies. Schematic diagrams (see Appendix) provide an aid to visualization of the interrelation of administrative levels and competences.

The civilian police authorities constitute the normal levels of general state administration when they assume the mantle of state power in dealing with police power concerns. The police authorities consist of the chief police

prosecutor's auxiliaries and not with police per se. For that reason, the figures may lump together with regular police the actions of the other auxiliaries of the prosecutor, such as customs inspectors or railroad security police. This fact should not significantly affect the statistics, however.) The police also ordered, without supervision, seizures of property (including drivers' licenses) in between $91.79 \%$ and $94.86 \%$ of the examined seizures (Beschlagnahmen). Id. at 227 . Yet the author of the study came to the conclusion that Gefahr in Verzug was arguably present only in approximately $64 \%$ of all searches, id. at 248 , and $84 \%$ of all seizures, id. at 250 . This finding may be interpreted as an additional sign of police discretion in not adhering to the supervisory framework of the substantive laws.

In a later study conducted in Berlin, J. Ehrhardt \& C. Kunze, Ordnungsverwaltung-im Schatten der Polizei: Untersuchungen zUm Verhältnis UND ZUR Zusammenarbeit von Ordnungsbehorden Und Polizei (1982), the authors attempted to isolate police law measures, that is, those undertaken by police acting for the local equivalent of police authorities when exercising their peacekeeping function. This study indicated that police acted under police law without supervision in ordering $59.57 \%$ of identity checks (Identitätsfeststellung); $40.42 \%$ of summons to appear in person (Vorladung); $38.29 \%$ of entries of commercial establishments (Betreten von Geschäften); $34.04 \%$ of sequestrations of property (Sicherstellung); $31.91 \%$ of entries to residences (Betreten von Wohnungen); $21.27 \%$ of searches of objects (Durchsuchung von Sachen); and $21.27 \%$ of searches of commercial establishments (Durchsuchung von Geschäften). Id. at 91. These various measures were often taken in concert. For example, the figures usually reflect double entries for the same occurrence under the categories of identity checks and personal summons. Id. at 91-92.

The numbers demonstrate that the police often act alone despite the substantive law's assignment of primary responsibility to other agencies. One may speculate that there is some difference in the degree of decisional authority shifted between activities in the crimefighting and peacekeeping areas. There is insufficient information to evaluate this apparent discrepancy, however, and it may only indicate a preference for informal conflict resolution by police in the area of peacekeeping. Given the tendency of the police to treat certain crimefighting matters as peacekeeping incidents, the more meaningful inquiry is probably what percentage of police work falls into each category (in both theory and practice). In this regard, it may also reflect methodological differences and a different sampling segment than that employed in Nelles's study. Ehrhardt and Kunze depended upon voluntary questionnaire responses for their data, and the response rate was relatively low. Nelles analyzed specific samples of existing case files at prosecutors' offices. It seems doubtful that Ehrhardt and Kunze's results are related to the fact that Berlin is one of the German jurisdictions in which police law has been reformed through the creation of Ordnungsbehörden as opposed to Polizeibehörden (as in Baden-Württemberg), see supra note 56 . To read between the lines, Ehrhardt and Kunze seem surprised that the independent measures of the police are as infrequent as they appear to be. This subjective impression may be grounded in the authors' political activism. Cf. J. EhrhardT \& $\mathrm{C}$. Kunze, Musterentwurf eines Polizeirechtstantes (1979) (politicized criticism of the Musterentuurf; see supra note 2). Regardless of the exact extent to which decisions have shifted to the police in either the crimefighting or peacekeeping areas, the shift has occurred to a significant degree. For this reason, bureaucratic and similar control functions gain importance. 
authority for the state, ${ }^{95}$ the regional police authorities, ${ }^{96}$ county police authorities, ${ }^{97}$ and the local police authorities (the mayor in smaller localities). ${ }^{98}$

The state law enforcement agency is organized on a statewide basis with distinct organizational units to serve localities. 99 Regional administrative districts (Regierungsbezirke), typically encompassing several county-sized administrative units, each have a regional office (Landespolizeidirektion) of the state law enforcement agency as its supervising facility. ${ }^{100}$ Under the regional law enforcement installation are local police facilities at the county or city level (Polizeidirektionen, or, in rural areas, specialized Kommissariate). Each of these local law enforcement facilities may be further divided into precincts (Polizeireviere) in urban areas or outposts of several officers in rural areas (Polizeiposten or Kriminalaussenstellen according to whether they are detective or uniformed patrol detachments). The regional law enforcement agency installation is intended to be an umbrella or supervising agency which is normally active only as an administrative instance; however, it does have its own officers in the field and the authority to command police operations of local installations. In practice, local law enforcement installations are responsible for policing in their localities and are superseded only in the case of special events such as spectacular crimes, demonstrations, or other public happenings which tax local police manpower.

Review and command channels ${ }^{101}$ for the law enforcement agency may be subdivided into three types of administrative review: normal supervision in the execution of duties (Dienstaufsicht), ${ }^{102}$ legality review (Fachaufsicht), ${ }^{103}$ and supervision of particular matters (Sachaufsicht). ${ }^{104}$ Dienstaufsicht extends to the organization and conduct of law enforcement at an institutional level as well as to personnel matters. ${ }^{105}$ Fachaufsicht consists of supervision and review of

95. PolG $\S 48$. The senior administrative level is normally the ministry responsible for the subject area of the law, and is for most matters of general government a section within the Ministry of the Interior. An example where this is not the case for an area of police concern would be traffic and road safety, which falls under the Ministry of Transportation (Verkehrsministerium).

96. Id. The intermediate administrative level of the general state administration (Regierungspräsidium) is exercised by a division within these regional authorities (for most matters the Public Safety Division, Number 11). See organizational chart referred to in note 40 for more detail.

97. PoLG $\$ 48$. County police authorities are a local level of state administration, typically the county administrative office (Landratsamt) or a larger incorporated municipality (Kreisstadt).

98. Id.

99. PoLG $\S \S 56,57,63,64$; Zweite Verordnung des Innenministeriums zur Durchführung des Polizeigesetzes $\S \S 3-21$, Baden-Württemberg GBl 440 (1968), as amended. Special units include highway details performing tasks similar to the state highway patrols in the United States, harbor and water police details active on the Rhine, and police reserve and training units. The description in the text is directed to the general law enforcement structure and not to special purpose units.

100. Regarding special treatment of Stuttgart, see note 39.

101. PoLG $\S \S 58-62$. See the schematic diagrams in the Appendix for a general view of the review and command channels.

102. Id. § 58 .

103. Id. $\S 59$.

104. Sachaufsicht is the prosecutor's administrative supervision over his auxiliaries in criminal investigations. E.g., R. BELz, supra note 46, at 225. See also supra notes 68-69 and accompanying text.

105. See R. BELz, supra note 46, at 250-51; H. MAURER, supra note 11, at 392. 
the legality (review of legal or jurisdictional prerequisites) and desirability (review of the exercise of discretion and individual decisions) of police measures. ${ }^{106}$

The power to give commands and the duty to channel information upward within the administrative hierarchy supports the relationship between the law enforcement agency installations and civilian police authorities. ${ }^{107}$ Responsible agencies for Dienstaufsicht or Fachaufsicht can give direct commands to the law enforcement agency installations, while these installations are duty bound to provide information to superior agencies in a form which will allow the latter to exercise their supervisory capacities. ${ }^{108}$

Within the law enforcement hierarchy, civilian police authorities at the intermediate administration level (Regierungspräsidium) and in the senior level of administration (Ministry of the Interior) exercise Dienstaufsicht over regional law enforcement facilities (Landespolizeidirektionen), while the regional law enforcement installations share review and supervisory powers over local police installations with these higher administrative levels. Fachaufsicht, however, is theoretically almost exclusively exercised by civilian police authorities: those in the senior level of administration supervise regional law enforcement installations, as well as local police authorities (civilian) up to the level of mayor in individual localities.

In rough terms, the above scheme sets forth the substantive law structure of intra-administration control. Supervision flows along the vertical chain of command, allowing review of police measures down to those taken by individual officers. Dienstaufsicht over the law enforcement agency is conducted chiefly by the police at the level between regional and local law enforcement installations. At a higher level, the regional governing authorities and the Ministry of the Interior (theoretically civilian) are responsible for supervision. Fachaufsicht is exercised over law enforcement installations by all levels of civilian administration (down to the level of local mayors in small hamlets). In general, supervisory power should lie with civilians located outside the law enforcement agency hierarchy. Since the state legislature exercises review over the ministries, there is also indirect accountability for police actions.

Intra-administration review can also result from citizen initiatives. In German administrative law, recourse for citizens dissatisfied with actions of the government consists first of the right to file an "administrative complaint" (Beschwerderecht). ${ }^{109}$ The complaint is the initial step in the challenge of an administrative act (Verwaltungsakt). ${ }^{10}$ Each public authority is legally bound

106. See R. BeLz, supra note 46 , at 252-54.

107. PoLG $\S 61$. See notes $111-15$ and accompanying text for actual practices limiting the flow of information.

108. PoLG \& 62.

109. At the constitutional level, article 17 of the German Federal Constitution (right of petition to redress grievances similar to the first amendment to the United States Constitution) regulates the relationship between the citizen and the State. The State is required to respond to its citizens insofar as it must provide administrative recourse for complaints directed against the exercise of state power.

110. See supra note 7 and accompanying text. 
either to evaluate any such complaint or to forward it to the responsible agency. This manner of triggering internal agency review is best understood as a function of the hierarchical administration (an aspect of its review and command functions). The duty to direct complaints to the responsible reviewing parties works in a horizontal fashion when complaints are distributed among government agencies. The vertical hierarchy stretching from the Ministry of the Interior as the senior supervisory body for both civilian police authorities and the law enforcement agency is, at the same time, a communication channel and chain of command.

In practice, supervision of the police peacekeeping function diverges from theory-as did the crimefighting relationship between police and public prosecutor. One significant reason for this divergence is a certain reluctance at the level of local law enforcement installations strictly to categorize typical complaints and distribute them horizontally to the responsible administrative instance. ${ }^{111}$

At a higher institutional level, an administrative practice exists whereby the chief of the regional law enforcement installation (Landespolizeidirektion) is appointed as head of the public safety division (police authority) of the regional administrative level of government (Regierungspräsidium). ${ }^{12}$ Thus, the chief policeman (typically a lawyer) is also the person responsible for supervision of local civilian agencies exercising their powers in most peacekeeping functions. This personnel congruence in effect restructures the supervisory function, which would otherwise run through civilians. ${ }^{113}$

In theory, Fachaufsicht provides a counterweight by opening a horizontal path to civilian police authorities on the local level, but in practice Fachaufsicht and Dienstaufsicht are barely separable. ${ }^{14}$ Most citizen complaints are confused recitations that something happened, without necessarily supplying detail relevant to their legal characterization.

Some local law enforcement installations attempt to separate Dienstaufsicht

111. Senior police management in local police stations offer a number of reasons for this practice. Common themes are: (1) the civilian administration would not understand the complaint in context; (2) in the case of mixed complaints, it is inefficient or unseemly to "split" a complaint and have two offices address its different aspects; and (3) citizens do not care who works on a complaint, so long as it is taken care of by the government.

112. The chief of the Landespolizeidirektion and his assistant are simultaneously assigned to head Section 11 (Public Safety) of the Regierungspräsidium under an organizational directive of the Interior Ministry (Polizeiorganisationserlass). See R. BELz, supra note 46, at 246, 247 (comment 12 to PoLG $\S 56$ ); see also supra note 96 and accompanying text.

113. Administrative practices differ to a certain extent between districts but, as an extreme example, in one Baden-Württemberg Regierungsbezirk in 1980 the person ultimately responsible for dealing with complaints was the in-house counsel and senior assistant to the district police chief. He was simultaneously in two administrative hierarchies (Polizeivollzugsdienst and Polizeibehörden) but was the ultimate recipient of complaints for both at the district level. In practice, he simply employed two different letterheads in his responses, choosing his stationery according to which of his administrative positions the complaint formally addressed.

114. Cases of pure Fachaufsicht complaints occur when police officers in emergency situations exercise the powers of the police authorities, which a disadvantaged individual then challenges as technically illegal to avoid imposition of costs, etc. Otherwise, the typical Fachaufsichtsbeschwerde involves the challenge of a parking ticket or moving violation on narrow grounds of alleged unlawfulness. 
from Fachaufsicht aspects of complaints (a determination normally made by the local police chief or a senior assistant), but many simply treat mixed complaints as matters of Dienstaufsicht. ${ }^{115}$ For this reason, many complaints remain within the police hierarchy despite a formal duty to inform civilian police authorities.

Sachaufsicht of the prosecutor is only Fachaufsicht in the area of crimefighting. This supervision, however, can occur only in the context of an ongoing criminal investigation. ${ }^{116}$ Whether the prosecutor ever becomes cognizant of the incident if the complainant chooses not to bring criminal charges against police for alleged misconduct (such as false imprisonment or assault) is determined by the fluid boundaries between the maintenance of order and crimefighting, and the contours of the criminal investigation.

\section{$\mathrm{V}$}

\section{Police Discretion in Practice}

With a sense of the institutional and legal culture influencing German police, a direct examination of police discretion can be made. The influence is observable on two levels: the institutional level, at which police management may make policy determinations; and the level of individual enforcement by police officers, where the question is whether any person who becomes the subject of police interest is treated like a similarly situated person. Discrimination per se is not at issue; the focus is rather on arbitrary enforcement decisions. While the institutional level of discretion involves a legal inquiry, isolating enforcement concerns entails a sociological inquiry.

\section{A. Police Discretion at the Institutional Level}

Theoretically, West German police act under the direction of civilian authorities, whether the prosecutor in crimefighting or the civil administration in peacekeeping. Despite the fact that German law incorporates this theoretical bias, in practice the police are established as an independent organization. The police are a professional force with their own internal review and statewide command structures, however, so independence does not imply freedom from control for individual officers.

It is probably a mistake to attribute to the police a direct desire to escape external controls in connection with the establishment of their institutional independence. Circumstances beyond the police's control have led to a serious weakening of the supervisory and command functions of superior civilian administrative officials. The police are secondarily affected by other agencies' problems. At the level of the prosecutor's office, high crime rates and inadequate staffing have led to a situation in which the police operate on behalf of but not under the immediate control of the public prosecutor. ${ }^{117}$

115. See supra note 111. In some police stations there is also an effort after the fact to inform responsible police authorities by sending them a copy of the complaint response. Administrative practices cover a broad spectrum, which indicates that at this level procedural treatment may be more significant than substantive law.

116. See supra notes $45-47,64-68,75-85$ and accompanying text.

117. W. STEFfEN, supra note 64 , at 267-68. 
In the area of civilian administration, the most significant explanation perhaps lies in the bureaucratic character of police authorities and the nature of the public safety task. The normal civil administration in its capacity as police authorities operates on a 8:30 a.m. to 4:30 p.m. weekday schedule. It is possible to overstate the case, but maintaining public order is an around-theclock matter. Police are forced to take immediate unsupervised measures much of the time. After-hours consultations with local civilian officials sometimes occur, but only in serious situations and only after a problem has worked its way up the police chain of command. Again, shifting to the police the practical authority to make decisions has not resulted from factors within their control. At most, police channel decisions at the level of after-the-fact review through their treatment of administrative complaints.

Evaluating the current state of affairs in terms of "discretion" is not a simple task, since the police colorably act under lawfully delegated authority in performing crimefighting and peacekeeping functions. The police exercise the authority of the public prosecutor and civilian administration. Tasks conceived in the nineteenth century have outgrown budgetary allocations while the underlying structure of the law and distribution of decisional authority have nót changed. ${ }^{118}$

When the police exercise their broad powers and make decisions designed for civilian authorities, do they exercise discretion? Viewed from the perspective of German law and the strict version of the rule of law, this question is susceptible of different answers. The availability of administrative and judicial review may limit the police's decisional scope much as it limits that of civilian authorities. By definition, however, this position is contingent upon the availability of administrative review (which may lose some attractiveness if it is police internal review instead of external civilian control) and the actual pursuit of judicial review by citizens.

The shifting of practical responsibility for decisions among institutions raises concerns in the West German system's own terms. To be "right," regardless of its content, a decision must be made by the proper authority. With regard to the exigent circumstances provisions under which police may act in place of other authorities, recent scholarship indicates a relatively high level of activity. ${ }^{119}$ As a matter of doctrine, special treatment of the theoretical exception is supported by an implicit characterization of police exercising

118. The doctrinal development has at least kept pace insofar as the Legalitätsprinzip has been extended to cover police as the prosecutor's auxiliaries. In a historical sense, the original reform scheme for criminal procedure, see supra notes 60-68 and accompanying text, did not foresee its application to the police as an independent institution. A small minority of academic commentators adhere to the view that the Legalitätsprinzip is not applicable to police because of the historic anomaly. E.g., F. Görgen, supra note 44. Practice has overtaken history, however, so the better modern view extends the Legalitätsprinzip to the police. E.g., V. GöTz, supra note 49, at 72 . It might be possible to read a similar expansion shaping the law as an effort to accommodate practice to the increased judicial review of police activities, see supra note 20 , but that may be overinterpretation.

119. See supra notes $90-94$ and accompanying text. The exact magnitude of the shift remains open to question since the currently available work is limited in scope and tentative in conclusions. 
the power of other authorities as those authorities themselves (the "prosecutor's auxiliaries," for example). By ex officio participation in the decisionmaking justification of these authorities, the police arguably act as part of the prosecutor's quasi-judicial office or the civil administration. It is a comfortable legal fiction, but police do not change their role in enforcement.

The letter of the law is preserved in special circumstance exceptions, but its spirit may be violated by the de facto migration of decisionmaking authority. To the extent the "wrong" party makes the decision and review is not pursued through the courts, what occurs is either (1) the functional equivalent of discretion in an unlawful decision not rectified or (2) the imposition of police-created enforcement policy as the basis of the decision.

\section{B. Police Enforcement Discretion on the Street}

To pass from institutions to the individual enforcement decision is to leave law and enter the realm of police sociology. The West German literature ${ }^{120}$ in this area is limited. ${ }^{121}$ Researchers have conducted a few studies in the crimefighting area, revolving around the relationship between public prosecutor and police in the administration of the Legalitätsprinzip. ${ }^{122}$ Other work has examined factors influencing selective enforcement of laws by the police (including the peacekeeping area) and the policies or principles which inform individual enforcement decisions. ${ }^{123}$

Relying consciously on American police sociology and criminological labeling theories, German sociologists in the late 1960's developed a theory of selective sanctioning by the police. ${ }^{124}$ This theory questions the legalistic

120. Much analysis suffers from unfortunate ideological hyperbole, with politically sensitized sociologists attempting to demonstrate the role of the police in alleged class justice. See, e.g., H. Scholler \& S. Bross, Grundzüce des Polizel- und Ordnungsrechts in der Bundesrepublik DEUTSCHLAND 1-11 (2d ed. 1978). Otherwise neutral analysis is often influenced in its premises by this existing literature. As a social institution under fire, see supra note 2, the police have drawn their share of politicized journalism. E.g., R. Gössner \& U. Herzog, Der Apparat: Ermittlungen in Sache Polizei (1982).

121. One non-German work bears special mention: R. Girtler, Polizei-Alltag: Strategien, Ziele Und STRUKTUREN POLizeilichen HANdelns (1980). This work, describing the operations of the Viennese police from the perspective of the observer-participant, was completed after much of the German work and consequently profited by the prior work's experience. Austrian law and society shares many features with Germany, so this work is generally comparable. 82.

122. Chiefly W. Steffen, supra note 64; E. Blankendurg, K. Sessar \& W. Steffen, supra note

123. See, e.g., J. Feest \& E. Blankenburg, supra note 72; J. Kürzinger, Private Strafanzeige und polizeiliche Reaktion (1978); Brusten, Determinanten selektiver Sanktionierung durch die Polizei, in Die Polizei: Soziologische Studien und Forschungsberichte 31-70 (J. Feest \& R. Lautmann eds. 1971); S. Hornthal, Analyse psychologischer Merkmale in Ermessen von Polizeibeamten (1975) (dissertation).

124. Brusten, supra note 123 , developed the theoretical aspects most clearly, alchough the same themes are present in earlier publications. See, e.g., Brusten, Selektive Sanktionierung durch die Polizei, [1969] Kriminologisches Journal. 2. The empirical work related to this position is from the circle of authors around Feest and Blankenburg (Arbeitskreis jünger Kriminologen), with J. FEEST \& E. BLANKENBURG, supra note 72, as perhaps the leading work. The literature is summarized as of 1976 in W. STEFFEN, supra note 64, at 44-50. The American connection exists through the tendency of this group to rely on American criminologists' work in formulating hypotheses to be examined in their 
analysis of discretion, and instead hypothesizes that it is "social discretion" which informs police actions. ${ }^{125}$ According to the theory's proponents, because police cannot act in a vacuum the legalistic discretion concept misconceives the police's position and effect on the social process. Strict compliance with the Legalitätsprinzip, requiring thorough investigation of all potential crimes, is not a realistic option; therefore, pursuit of individual offenses is presumably a matter of police discretion. Under this theory, selective sanctioning arose because ambiguous expectations are directed at police and their internal resource allocation decisions. ${ }^{126}$ The selective sanctioning was channeled, however, by the social choices of the police.

Sociologists also advance the theory that the subjective goal of police operations is to produce visible success in the form of a high solution rate for reported crime. ${ }^{127}$ Unpromising crimes are either never recorded or not actively pursued, since police effort not resulting in crime-solving would be wasted. At the same time, police develop their own operational criteria for suspicious behavior. Under this approach, policemen on patrol do not concentrate on solving individual crimes, but rather exercise discretion in attributing criminality to specific classes of alleged offenders and investigating them. ${ }^{128}$ As a result, criminalization is concentrated among groups drawn predominantly from the working class. ${ }^{129}$

In 1969, an observer-participant ride-along patrol study was conducted in a large German city. ${ }^{130}$ This study complemented earlier, nonempirical work investigating the ability of the police to use their position to characterize the social situation in certain terms. ${ }^{131}$ Its authors hypothesized that this discretionary power of definition (Definitionsmacht) works on a class-specific basis. Decisional criteria for the police in undertaking action are typified as: (1) the neighborhood in which a suspect is encountered; (2) the suspect's appearance; and (3) his behavior as understood by the police. ${ }^{132}$ The context for police-suspect encounters in which police discretion comes to the fore involves incidents of "suspicious" behavior, conflict situations, and minor offenses. Resolution of these incidents implicates the social values and prejudices of the police. On the whole, the police role on the street consists more of maintaining order (controlling situations) than of crimefighting. ${ }^{133}$

The patrol study implicitly assumes that policemen riding in patrol cars deal with concrete situations rather than the doctrinal categories of

\footnotetext{
German studies. J. Feest \& E. Blankenburg, supra note 72 , is in part an attempt to replicate the work of Jerome Skolnick in a German context.

125. J. Feest \& E. Blankenburg, supra note 72, at 17-19.

126. Brusten, supra note 123 , at $40-41$.

127. See id. at 45-49.

128. J. Feest \& E. Blankenburg, supra note 72, at 35-57.

129. Brusten, supra note 123 , at 41-45, 47-49.

130. J. Feest \& E. Blankenburc, supra note 72. This south German city is located outside Baden-Württemberg.

131. Id. at 45-55.

132. Id. at 36-39.

133. Id. at 86-113.
} 
crimefighting and peacekeeping. Legal definitions justifying actions are applied after the fact. In practice, police develop an interest in a person as "suspicious" and manufacture grounds for investigation. For example, police might stop a car for malfunctioning tail lights when their real goal is to examine the car and determine the driver's identity. ${ }^{134}$

The study captures several important aspects of West German police operations. It explores the difference in attitudes and expectations between patrolmen and police management at the precinct level and higher. ${ }^{135}$ This distinction has been pursued in later studies that distinguish between the legal knowledge imparted to cadets at the police academy and professional socialization occurring in the course of probationary training periods (conducted in the company of experienced policemen). ${ }^{136}$ If discretion is influenced by norms below the statutory level, it is most likely through the formal or informal educational process.

The definitional power of the police is viewed as a social manifestation of the ignorance and vulnerability of working class suspects. Without knowledge of their rights, these suspects are subject to the policeman's mastery of the laws. Middle and upperclass suspects, however, possess the means to challenge the police's view of a given situation. Furthermore, the same suspect, by virtue of education or position, possesses the presumed social ability to make life difficult for the policeman (by challenging the latter's characterization of the situation through exercising powers of complaint or Beschwerdemacht). Beschwerdemacht is best understood as a practical awareness of the possibilities of judicial and administrative review of police actions coupled with the complainant's inherent credibility before the reviewing authority. ${ }^{137}$

A 1975 Hamburg study ${ }^{138}$ expressly focused on police discretion by testing the reactions of patrolmen to minor traffic law violations (which are petty offenses or Ordnungswidrigkeiten subject to the Opportunitätsprinzip). The study attempted to isolate psychological factors affecting the exercise of discretion. Police officers were presented with a variety of situations involving

134. As a supporting example, during the peak of terrorist activity in the 1970's, association with certain causes of the extreme left was treated as grounds for suspicion among security-conscious West German police. Numerous cases arose involving demonstrators' efforts to have courts order destruction of fingerprints and identity information taken by police in connection with arrests which were challenged as based solely on a desire to identify political sympathizers of radical leftists. Similarly, street vendors of extremist publications complained of harassment in the form of fingerprinting and identification measures after being taken into custody on charges that they were peddling merchandise without a license (alleging discriminatory enforcement to establish their identity).

135. See, e.g., J. Feest \& E. Blankendurg, supra note 72, at 27-31.

136. See, e.g., R. Spiegelberg, Qualifikatorische Aspekte der Sozialisation in den Polizeiberuf unter besonderer Berücksichtigung der Einstellungsänderungen gegenüber dem Publikum (1977) (dissertation).

137. J. Feest \& E. BlankenburG, supra note 72, at 46-50, 81-83, 108, 112.

138. S. Hornthal, supra note 123 . This study was conducted by a psychologist outside of the group Arbeitskress jünger Kriminologen otherwise responsible for much of police sociology, see supra note 124. It reviews their work relating to police discretion, $S$. Hornthal, supra note 123 , at 8-10, but is not commonly cited by German scholarship in reviewing police studies. However, it does represent a rare study of discretion on the enforcement level. 
traffic violations. ${ }^{139}$ They could respond by making the threshold decision of whether to issue a Verwarnung (the functional equivalent of a ticket) and then by deciding how much offenders should be fined. The following variables were altered among the hypothetical offenders: (1) age; (2) sex; (3) polite reaction to address by the officers; (4) acceptance by offenders that they had committed a meaningful violation; and (5) social status. ${ }^{140}$ To place the test in context, an official publication (Bussgeldkatalog) sets forth a range of recommended fines for various traffic offenses, advising higher or lower ranges depending on whether the violation would be considered a minor or serious violation of the same legal rule. Police normally do not work with this "tariff" in hand, but they are presumed to employ its general ranges in practice. ${ }^{141}$

The results of the study qualify the social discretion concept advanced in sociological work. In articulating decisional grounds, many police indicated that legal definition in terms of the elements of the offense was of greater importance to them than social factors such as politeness, acceptance of the violation, or social status. ${ }^{142}$ In this sense, training and knowledge of the law did make a difference in the actions of the officers. Furthermore, there was a correlation between knowledge of enforcement guidelines and actual fines levied. ${ }^{143}$

The study showed no significant correlation between the amount of the fine and age, sex, or social class. Offenders were punished significantly more often and with higher fines, however, if they were not polite or did not acknowledge that they had violated the law. ${ }^{144}$ This behavior differed from certain assumptions of the original labeling school theorists relating to social perceptions and class justice. ${ }^{145}$

The test subjects' personal state of mind played some role, since police with more authoritarian personalities gave higher fines, while those dissatisfied with their jobs fined less often. The study concluded that police aggression when meeting offender resistance is in the nature of a personal reprisal. In this sense, the exercise of discretion is in effect punishment of the offender for his or her post-violation conduct and is not functionally related to the offense committed.

139. S. Hornthal, supra note 123 , at 11-37.

140. Id. at 15-18.

141. The test subjects were drawn from the ranks of patrolmen, although a certain number were in training for promotion to police middle management. The first stage of the tests elicited responses to written descriptions of situations. The responses were then compared to related peer evaluation inquiries for a different group of police subjects. These results confirmed those of the written hypothetical test. Test subjects were also asked a number of questions to determine their knowledge of both substantive law and the published recommendations for fines and were given personality tests.

142. See S. Hornthal, supra note 123, at 126-27.

143. It is possible that more knowledgeable police officers simply took written tests better. However, the correlation with evaluations in the second half of the test gravitates against this conclusion. The behavior of all officers, reacting to different social situations, indicated that their reaction was to the situation presented to them in the test and not to the testing process itself.

144. The author of the study found instances of this behavior to be significantly present in otherwise factually varying cases, $S$. Hornthal, supra note 123, at 79-84.

145. Id. at 127-29. 
The study also concluded that social justice would best be achieved through focusing police training and education on the suggested norm-the substantive offenses and recommended responses to violations. ${ }^{146}$ The influence of personality, social views, and situational externalities should be reduced to a minimum. Acceptable considerations for discretion require development, but the manner of violation (whether cold-blooded), excusability of an offense, degree to which others are endangered, and damage incurred are suggested as legitimate considerations. By isolating such factors and educating officers, the police would presumably achieve greater conformity when exercising the recommended discretion in enforcement.

A 1976 study 147 of police criminal investigations based on group interviews and court file analysis isolated several selection criteria for police crimefighting activities. Three factors were determined to influence the police's decision whether to allocate resources to the serious investigation of a given offense: (1) the visibility of an offense to outsiders as expressed in differential reporting rates of crime, with the result that individual reports of high volume offenses might not receive serious attention; (2) the probability of isolating suspects for the offense (based on experience with the type of reported crime, police might choose not to pursue reported offenses if no suspect were immediately known); and (3) the degree of difficulty of proving that a specific suspect had committed a given crime, assuming that he had been identified. ${ }^{148}$ This study concluded that police do not pay undue attention to considerations of social position in making enforcement decisions, although a suspect's youth was found to affect the likelihood of active investigation pursued to the point of conviction. ${ }^{149}$ Rather, police concentrated mainly on factors related to individual offenses.

A 1978 study ${ }^{150}$ conducted in the small town suburb of a regional population center attempted to measure police reactions to private parties' reports of certain minor crimes by means of observer-participation (as a reserve policeman) and the review of police records. The study found that, in practice, police differentiate among offenses in deciding whether to register such reports (even where the Legalitätsprinzip mandated it). ${ }^{151}$ Individual policemen act as filters for reports of offenses. Under certain circumstances, policemen

146. Id. at $130-32$.

147. W. Steffen, supra note 64 .

148. Id. at 292-93. The third factor was found only to affect the intensity of investigation insofar as more resources were invested in the effort (despite the apparent lower probability of success in some cases). The objective criteria for cases considered difficult to prove may, however, provide an explanation. Typically, cases involving confessions and suspects with prior criminal records were considered to be easier, while difficult cases involved circumstantial evidence.

149. Id. at 293 .

150. J. KürzINGER, supra note 123.

151. The complaints typically involved reports of offenses after their commission-as opposed to those discovered by the police in progress-and so allowed an analysis of crimefighting activities less influenced by peacekeeping concerns. The offenses in question were also minor offenses in a special class on the level of theft and assaults close to the lower boundaries of the Legalitätsprinzip (Antragsdelikte). 
try to talk individuals out of reporting minor offenses. ${ }^{152}$ The study concluded that a majority $(70 \%)$ of reported offenses against the person are not taken down in written reports. ${ }^{153}$ In contrast, $97 \%$ of reports of offenses against property are recorded in a written report. ${ }^{154}$ The creation of a written record automatically enters the incident into crime statistics and is a necessary condition to active criminal investigation. On this basis, the study concluded that loss of property is more likely to lead the police to pursue criminal investigations than those offenses against the person which do not lead to any serious or lasting injury. ${ }^{155}$ This conclusion is qualified by the fact that only minor infractions were involved in all cases.

The literature of police studies demonstrates apparent police discretion in application of the Legalitätsprinzip. This conclusion is not surprising insofar as practically all studies begin with the premise that even if the police desire to fulfill all tasks assigned by lawmakers, they lack the resources. The discretion alleged by most researchers is selective enforcement of laws and not overenforcement. This police activity may reflect conscious decisions, but are these decisions policy determinations usurping lawmakers' prerogatives? One approach in the literature theorizes that the police's own social prejudices and values make them an instrument for the criminalization of selected offender groups, while another sees the rational allocation of scarce resources as the engine of choice.

To the extent that police do not receive adequate material resources to fulfill tasks assigned by lawmakers, it seems misleading to characterize choices forced upon the police as the "exercise of discretion." Social selectivity theories typically infer a police enforcement policy only by assuming common social backgrounds and values for policemen as a group (which are brought to the fore in police enforcement). Individual enforcement decisions based on personal values undoubtedly occur, but assigning values to the police across the board ignores diversity and internal organizational tension.

Interesting problems exist at the enforcement level due to divisions within the police, which problems are noted but not fully addressed in this article or the German literature. The goals and attitudes of police management do not necessarily coincide with those of officers on patrol. Subjectively, police management adheres more to a theoretical legal model, except insofar as it may have attempted to establish the police as an independent institution. The individual policeman on patrol is more interested in securing social peace and avoiding wasted personal effort. He pays correspondingly less attention to

152. J. KÜRZINGER, supra note 123, at 215-18.

153. Id. at 227.

154. Id.

155. Id. at 236-37. Individual policemen challenge any general property bias interpretation, however, on the basis that the reports of offenses against the person typically involve domestic disputes. Policemen state that the peculiar posture of domestic disputes leads them to neglect this category of offenses. The complainant may file a complaint, but after reconciliation will refuse to follow it through with evidence at trial. On that basis, police view active prosecution of such complaints usually as a waste of time. 
technical requirements in responding to situations. This internal tension seems less a matter of the exercise of police discretion (understood as policyoriented) and more a supervision and management concern.

Another apparent direction of discretion involves the police's decriminalization of potential offenses by treating them as peacekeeping matters. In most cases, the police's own categorization of the police measure is decisive. The tendency of officers on the beat to deemphasize fighting crime in favor of maintaining public order (at least in cases of less serious offenses) results in a situation in which a criminal offense may be present but the police act only to maintain order. For example, a fist-fight in a bar should result in the opening of a criminal assault investigation, but the police commonly take the offenders into police custody (not criminal arrest) to let them sober up in the drunk tank. Unless there is property damage in the bar, no one but the troublemakers has grounds to complain about police actions (and they naturally will not challenge the police's failure to file charges against them). So long as the policeman perceives his chief role as keeping the peace, the competing concerns and decision whether a particular police measure serves the peacekeeping or crimefighting function make for ambiguity. This is the most visible area in which police judgment replaces that of lawmakers; however, in this situation the police's actions are typically on the borderline between crimefighting and peacekeeping functions. Rather than unauthorized policymaking, any pattern may represent a post hoc aggregation of individual enforcement decisions. This behavior may also be the subject of an implicit analysis that criminalization is a waste of effort for these minor matters (a potential policy decision), but it conceivably relates back to resource allocation concerns.

VI

ReLEVANCE OF THE CoMPaRATIVE INQUiRy For the American Situation

In a cross-cultural inquiry, any conclusions must remain at the level of analogy and implicit comparison. With that caveat, the following are offered as lines of further inquiry addressed to the American situation.

It is possible to both articulate standards for discretion and establish judicial and internal governmental review of its exercise under given circumstances. This possibility raises issues of whether and why the police should be treated differently from other governmental agencies. Moreover, controlling or channeling police discretion would require more than simply changing a few statutes. American police are active in areas outside of criminal justice; limiting discretion in those areas would require a different institutional and political outlook. At a minimum, it would be necessary for the judiciary to engage in review of day-to-day executive decisions to an extent foreign to the American lawyer. Due to the highly visible collision of individual rights and government power, however, American police activities in criminal law enforcement are already subject to significant judicial examination. 
West German police may have discretion thrust upon them by practical budgetary constraints. Discretion becomes the choice of which tasks to neglect when it is not possible to do everything. In the American context, the choice between fewer legal norms to enforce and more resources for enforcement is a question on which reasonable men may differ. Unless this choice is made by lawmakers, however, it may be misleading to concentrate on selective sanctioning as unwanted police discretion in enforcement. ${ }^{156}$

By virtue of outlook and incentives, police on patrol may concentrate on peacekeeping in dealing with conflict situations. This fact bears repeating, since lawmakers' plans for police are often constructed with legal categories from the crimefighting/law enforcement end of the spectrum. The failure of police to adhere to the strict categories may result from a conflict between lawmakers and the police over the latter's primary role. Some police discretion in selective enforcement may result from lawmakers' misunderstanding of the functional enforcement possibilities in general. Misconceived statutory schemes will be met with selective enforcement (or nonenforcement), so lawmakers' failure to consider enforcement practicalities in the lawmaking process may itself encourage police discretion.

Discretion at the enforcement level may be channeled through training. Training should inculcate certain standards upon which policemen can draw in practice. The question remains who should formulate these standards and what factors should be taken into account, but this may be no more difficult than, for example, the statutory formulation of sentencing considerations for judges. Such official recommendations regarding enforcement should not be rejected as too theoretical for police operations.

Channeling discretion through training requires a high level of long-term effort. If it is any indication, considerably more time and effort are devoted to police training in Germany than in the United States. Additionally, German police training is structured differently in that training at career commencement (and at shifts between various rank groups) predominates over the type of continuing professional education popular with American police. The long initial training of German police is followed by relatively active supervision by police management. Although there are inherent limitations in deskbound supervision of officers on patrol, it can be made more effective through the feedback mechanism of complaints.

An interesting corollary to the positive side of training is that lack of training may have the regrettable effect of increasing arbitrariness in decisions. On-the-job training should not be relied on to fill this gap, since without direction from senior police management this version of professional

156. In this context, the question of discretion and the rule of law as presented by Professor Davis, see supra note 1, bears reexamination. Harking back to his strawman of the reasonable versus extravagant versions of the rule of law it appears that, at least in the German context and for German courts, see H. MAURER, supra note 11 , at 96-97, the strict or extravagant version limiting police discretion in substantive law provides a framework for evaluating discretion in enforcement. Budgetary constraints do affect practice, but they cannot say anything about the quality of actions actually taken. 
socialization will not inculcate lawmakers' values. Without discretion-channeling values provided in training, the patrolman is left with his own opinions. Even with the best intentions, there can be no uniform enforcement. In terms of social selectivity, discriminatory enforcement may be more likely where there is no competing set of official guidelines enforced by police management.

Although comprehensive civilian supervision is a difficult goal in practice, conscientious operational management of the professionalized police force may achieve the same result. Assuming realistic enforcement standards exist, their implementation is best conceived of as a managerial process in the nature of quality control. Enforcement guidelines are, in this light, performance specifications. Internal administrative controls may require the threat of judicial review or other external sanctions to ensure that they are followed in practice, but positive incentives and training are better guarantors of performance. 







\section{APPENDIX}

\section{Diagram 2}

\section{Organization and Personnel of the Baden-Württemberg Police*}



- The number of officers given is from the 1979 budget and represents budget allocations, not actual personnel. The difference is not material in practice. 


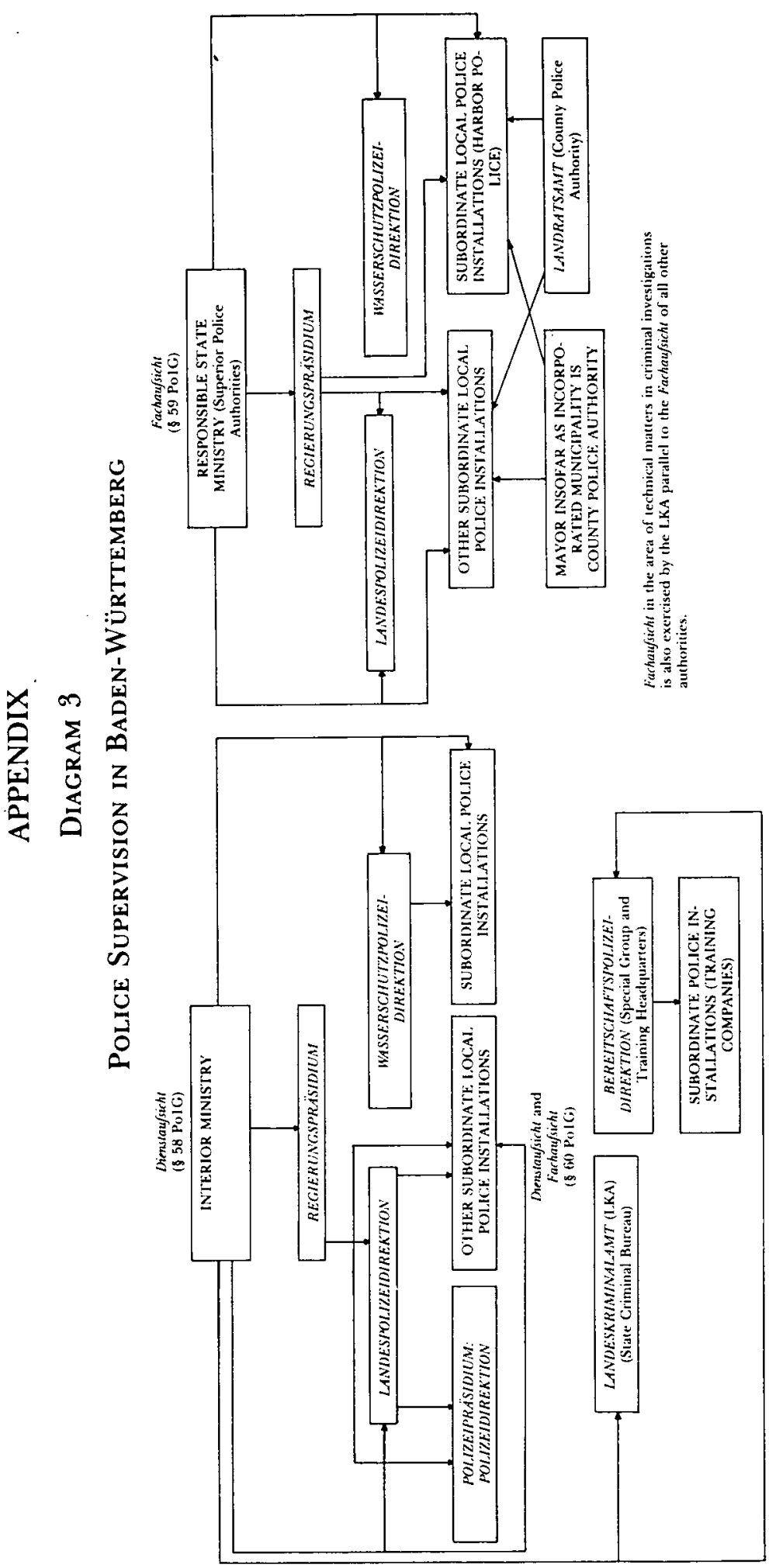


